\begin{tabular}{lll}
\hline Mezhep Arassttrmaları Dergisi & 13, sy. 1 & (Bahar 2020):249-283 \\
\hline Journal of Islamic Sects Research & 13, no. 1 & (Spring 2020):249-283 \\
\hline Hakemli Arastırma Makalesi | Peer-reviewed Research Article
\end{tabular}

Hakemli Araştırma Makalesi | Peer-reviewed Research Article

\title{
Alevi-Bektaşi Yolunda Dört Kapı Kavramı
}

\author{
The Concept of Four-Gate on the Road of the Alevi-Bektashi
}

Belief

Alirıza ÖZDEMİR ${ }^{1}$

\begin{abstract}
Öz
Aleviliğin eğitim müfredatının merkezinde yer alan Dört Kap1, bireysel olduğu kadar toplumsal eğitimin de mihenk taşıdır. İnsanı, olgun yani kâmil hâle getirmeyi, toplumu ise rizalık temelinde inşa etmeyi hedefleyen bu eğitim programı, inancın içselleștirilmesi ve davranışa dönüştürülmesi için takip edilen süreci ifade eder.

$\mathrm{Bu}$ çalışmada Aleviliğin yazılı kaynaklar1, yani buyruk ad1 altında toplanan eserler, erkânnâmeler, velayetnâmeler, icazetnâmeler, şecereler ile Alevi ariflerine ait risaleler ve şiirler esas alınarak Alevilikteki Dört Kap1 programı incelenmiştir. Programın kaynakları, temel özellikleri, ana çerçevesi, hangi mecazlarla ifade edildiği gibi birçok konu Aleviliğin iç metinlere bakılarak karş1laştırılmıs, benzer ve farklı yönleri ortaya konulmuştur.

Makalede cevabı aranan sorular șunlardır: Aleviliğin yazılı kaynaklarında Dört Kap1 kavramının kökeni nereye dayandırılmıştır? Dört Kapı programının temel özellikleri nelerdir? Dört Kapı kavramı hangi mecazlarla ifade edilmiştir? Dört Kap1 kavramının ana hatları nasıl çizilmiştir? Dört Kap1 ile kişinin hangi hedeflere ulaşması öngörülmüştür? Şeriat, Tarikat, Marifet ve Hakikat (Sirr-1 Hakikat) kapilar1 birbirinden bağımsı mi, yoksa birbirini takip eden
\end{abstract}

Abstract

The concept of Four-Gate (Dört Kap1) is the cornerstone of both community and individual education and located at the center of the educational curriculum of Alevism. This educational program, which aims to make people mature, that is, to build a society on the basis of consent, expresses the process followed to internalize belief and turn it into behavior.

This study aims at examining the Four-Gate program in Alevism based on the written sources of Alevism, namely the tales and poems belonging to the Alevi scholars, the works collected under the name of the Buyruk, Erkânnâme, Velayetnâme, Icazetnâme, and Şecere. Many aspects such as the sources, basic features, main framework and the metaphors of the program were compared by looking at the inner texts of Alevism, and the similar and different aspects were revealed. The article tries to answer the following questions: Where did the concept of the Four-Gate originate in the written sources of Alevism? What are the main features of the Four-Gate program? In which metaphors is the concept of the FourGate have been expressed? How

1 Uzman, MEB, Ankara, Türkiye, e-posta: allik24@hotmail.com, ORCİD: 00000002-9046-3169.

\begin{tabular}{ccc}
\hline $\begin{array}{c}\text { Başvuru|Submission } \\
\text { 25.04.2020 }\end{array}$ & $\begin{array}{c}\text { Kabul|Accept } \\
26.06 .2020\end{array}$ & $\begin{array}{c}\text { Yayın | Publish } \\
30.06 .2020\end{array}$ \\
\hline DOI & 10.18403 /emakalat.726623 &
\end{tabular}


süreçler seklinde mi ele alınmıștır? Çalışmada Aleviliğin yazılı kaynaklarında Dört Kapı'nın dayanakları, temel özellikleri, mecazları, hedefleri ve ana çerçevesi hakkında birbirini tamamlayan genel bir uyum olduğu sonucuna ulasslmiștır.

Anahtar Kelimeler: Dört Kap1, Kırk Makam, Alevilik, Bektaşilik, Yol. was the Four-Gate concept outlined? Which goals are the individuals foreseen to be achieved by the concept of Four-Gate? Are Şeriat, Tarikat, Marifet, and Hakikat (Sirr-1 Hakikat) doors handled independently or as successive processes? The study concludes that the written sources of Alevism complemented each other with respect to the foundations, basic features, metaphors, goals of the concept of FourGate.

Key Words: Four-Gate, Fourty Rules, Alevism, Bektashism, The Road.

\section{Giriş}

Aleviliğin eğitim sisteminin ana bileşenlerinden biri olan Dört $\mathrm{Kap1}^{2}$, hem bireysel hem de toplumsal eğitimin temel programıdır. İnsan1, olgun yani kâmil hale getirmeyi, benliğiyle, toplumla, doğayla ve Tanrı'yla barışık yaşamayı; toplumu ise rızalık temelinde yeniden kurmayı ve ergin bir sosyal yapı inşa etmeyi hedefleyen bu eğitim programı, inancın kabulü, içselleştirilmesi ve bir yaşam biçimine dönüștürülmesinde takip edilmesi gereken süreci ifade eder. Şeriat, Tarikat, Marifet ve Hakikat (Sirr-1 Hakikat) adlarını taşıyan Dört Kapı'nın her birinde, ayrıca makam adı verilen yedili veya onlu ara basamaklar vardır.

Bu çalışmada Aleviliğin yazılı kaynakları, yani buyruk adı altında toplanan eserler, erkânnâmeler, velayetnâmeler, icazetnâmeler, şecereler ile Alevi ariflerine ait risaleler ve siirler esas alınarak Alevilikte Dört Kap1 programı değerlendirilmiștir. Makalede kullanılan kaynakların tamamı Aleviliğin iç metinleridir. Calısma boyunca Alevi kavramıla Kızılbas ve Bektași toplulukları ifade edilmiștir. Teknik detayları doğru aktarmak için ihtiyaç duyuldukça Kızılbaş ve Bektassi kavramları ayrı ayrı kullanılmıştır. Ayrıca metin içinde açıklanmasına ihtiyaç duyulan eklemeler tarafımızdan köşeli parantez [] içinde yapılmıştır.

2 Alevi-Bektaşi yazınında Dört Kapı genellikle Kırk Makam'la birlikte anılır. Ancak bazı kaynaklarda makamların sayısı yirmi sekiz olarak verilmiştir. Bu nedenle makalenin başlığına makam sayısı ifade edilmemiştir. 
Makalede, Aleviliğin yazılı kaynaklarında Dört Kapı kavramının kökeninin nereye dayandırıldığı, temel özelliklerinin neler olduğu, hangi mecazlarla ifade edildiği, ana hatlarının nasıl çizildiği incelenmiştir. Ayrıca Dört Kap1 programıla kişinin hangi hedeflere ulaşması gerektiği ele alınmıştır. Şeriat, Tarikat, Marifet ve Hakikat (Sırr-1 Hakikat) kapılarının birbirinden bağımsız m1, yoksa birbirini takip eden süreçler mi olduğu soruları cevaplanmıştır. Programın kaynakları, ana çerçevesi, hangi mecazlarla ifade edildiği gibi birçok konu Alevilikteki iç metinlere bakılarak karşılaştırılmış, konunun benzer ve farklı yönleri ortaya konulmusstur. Alevi olmayan diğer Müslüman toplumlarda Dört Kapı kavramı ve Dört Kapı'nın makamları bu çalışmanın dişında bırakılmıştır. Bu konular ayrı başlıklar altında çalışılmalıdır.

\section{Bulgular}

\subsection{Dört Kapı'nın Dayandırıldığı Kaynaklar}

Aleviliğin yazılı kaynakları, Dört Kapı kavramının temelini tümüyle İslâmi referanslara dayandırır. Bunlar bașta kutsal kitap Kur'an-1 Kerim olmak üzere Hz. Muhammed, Hz. Ali ve İmam Cafer Sadık gibi İslâmi kişiliklerin sözleri ve uygulamalarıdır. ${ }^{3}$

İmam Cafer Buyruklarının Hacıbektaş-1 yazmasında, Dört Kap1 Kırk Makam'ın kaynağ1 "Hazreti Kur'an" olarak gösterilir. ${ }^{4}$ Böylece Kur'an-1 Kerim'in ayetleri, Dört Kapı kavramının temel dayanağ olarak kabul edilir.

Şeyh Safi Buyruklarından birinde Dört Kapı'nın kaynağı, Hz. Muhammed'in sözlerine dayandırılır. Hz. Muhammed ise bu bilgiyi vahiy meleği Cebrail vasıtasıyla Allah'tan almıştır. Aktarıma göre Hz. Muhammed, bir gün Hz. Ali'yi yanına çağırarak Hakk'a yürüme vaktinin yaklaştığını, dünyadan ahirete gideceğini ve ona birkaç vasiyette bulunacağını söyler. Bu vasiyetlerin Allah katından Cebrail vasıtasıyla geldiğini, bunları iyi dinleyip uygulamasını, çünkü uygulayanların iki cihanda aziz ve muhterem olacağını sözlerinin başında belirtir. Hz. Muhammed'in bildirdiğine göre, Şeriat peygamberlerin, Tarikat ise velilerindir. Marifet irfan yolunda yürümek, peygamberlerin ve velilerin yolunda gitmektir. Hakikat ise vuslat yani kavuşma makamıdır. Cenab-1 Hakk'la hak olmaktır. Ümmetten özel ve tertemiz inanca sahip olanlar bu öğütleri can kulağı ile dinleyip bellemelidir. Bunlar inci mercandan daha kiymetli bilgilerdir. $\mathrm{Bu}$ vasiyetlere uyanlar, mahşer günü kıyamet koptuğunda $\mathrm{Hz}$. Mu-

\footnotetext{
3 Burada Dört Kapı'nın kaynakları, telif tarihine göre değil önem sırasına göre incelenmiştir.

${ }^{4}$ Buyruk, nşr. Sefer Aytekin, (Ankara: Emek Yayımevi, 1958), 219.
} 
hammed'in bayrağ ve sancağı altında toplanıp onun şefaatine erişecektir. ${ }^{5}$ Anlatının devamına göre, Hz. Ali başka öğütler de içeren bu vasiyeti $\mathrm{Hz}$. Muhammed'in yanında kaleme alarak büyük ve değerli bir kitap haline getirir. Bu kitap önce Hz. Ali'nin büyük oğlu İmam Hasan'a sonra küçük oğlu İmam Hüseyin'e ve ondan sonra İmam Hüseyin'in oğlu İmam Zeynelabidin'e erişir. ${ }^{6}$

1612 tarihli Manisa Şeyh Safi Buyruğuna göre Dört Kapı'nın kaynağı miraç olayıdır. Hz. Muhammed miraca çıktığında Allah ile doksan bin kelam konuşmuştur. Bunun yirmi bini Marifet, otuz bini Hakikattir. ${ }^{7}$ Aynı buyruk metninin 20. Yüzyılın hemen başında çoğaltılan bir nüshasında ise doksan bin kelamın doksan bin kelamin otuz bininin șeriat "kafi", otuz bininin "yolu", otuz bininin hakikat "hali" olduğu söylemiștir. Marifet kelamının ise "sırrı emir" olduğu ve Hz. Ali'nin "kudret nurunda sır edildiği" bildirilmiştir. ${ }^{8}$

Yunus Emre (13-14. yüzyıl), "Doksan bin kelimeyi Hak / Söyliyecek Habib ile / Otuz bini sir olucak / Ben ol sirrolanda idim" 9 diyerek doksan bin kelama ve otuz bininin sir olduğuna değinir. Yine Yunus Emre, başka bir şiirinde doksan bin kelam ile özel / sır olan otuz bin kelama temas eder: "Doksan bin Hak kelamı altmış bin hâs a âmı / Otuz bini hass'ül - has oldurur sır içinde."10

16. yüzy1l erenlerinden Kul Himmet, bir nefesinde doksan bin kelamı kapılara göre şöyle paylaştırır: "Doksan bin kelamı şerh etti buldu / Kimin nihan kimin aşikâr oldu / Otuz bini belli şeriat doldu / Seddetti bağladı nefs-i avâmı / (...) / Otuz bin tarikat iptida hali / Evvel rehberinden sundular eli / Gösterdi erkânı sürdüler yolu / Hoss bekle dediler post ile kiyamı (...) / Otuz bin marifet zat sıfat olmaz / Aslı türabidir kumları gelmez / Doksan bin hakikat değmeye ermez / Tanış rehberinle bozma nizamı."11 Hacı Bektaş Veli Dergâhı postnişinlerinden Hamdullah Çelebi (1767-1836) "Hasreti" mahlasıyla yazdığı bir şiirinde benzer göndermeler yapar: "Otuz

5 Şeyh Safi Buyruğu, nşr. Kaplan, (Ankara: Türkiye Diyanet Vakfı Yayınları, 2015), 37-39.

6 Şeyh Safi Buyruğu, 43; Ayrıca bkz.: Ahmet Taşğın, Irak'ta Mezhep Çatışmalar Arasında Alevîler Ve Bektaşîler, (İstanbul: Önsöz Yayınc1lık, 2012), 109-111.

7 Bisati, Şeyh Safi Buyruğu, nşr. Ahmet Taşğın, (Konya: Çizgi Yayınları, 2003), 17. Metinde sadece bu kadar bilgi verilmiştir. Geriye kalan 40 bin kelam hakkında bilgi verilmemiştir.

8 Yunus Koçak, "Şah İbrahim Ocağı'ndan Gelen Bir Şeyh Safi Buyruğu”. Hacı Bektaş Veli Araştırma Dergisi, 30 (2004): 66-67.

9 İsmail Özmen, Alevi-Bektaşi Şiirleri Antolojisi, (Ankara: Kültür Bakanlığı Yayınlar1, 1998), 1/111.

10 Özmen, Alevi-Bektaşi Şiirleri Antolojisi, 1/134.

11 Özmen, Alevi-Bektaşi Şiirleri Antolojisi, 2/297. 
bini SSeriatta / Otuz bini Tarikatta / Otuz bini Hakikatte / Bilenler bildi billahi". ${ }^{12}$

Hacı Bektaş Veli'nin öğütlerini içeren Fevaid adlı risalede $\mathrm{Hz}$. Muhammed'in şöyle dediği aktarılır: "Şeriat sözlerimdir, Tarikat fiillerimdir, Hakikat hallerimdir, Marifet elde ettiğim sermayemdir."13 Benzer anlatımlar geleneğe ait âdâb ve erkân kitapları niteliğinde olan Buyruk yazmalarında da görülür. İmam Cafer Buyruğunun İzmir yazmasında, yola varmak için dört şeyin gerekli olduğu ve bunların Şeriat, Tarikat, Marifet ve Sırr-1 Hakikat'ten oluştuğu ifade edilir. Metnin devamında Şeriatın Hz. Muhammed'in hükümleri, Tarikatın din içindeki fiiller, Hakikatin hak yoldaki haller ve Marifetin ise iman içindeki erkân olduğu bildirilir. ${ }^{14}$ Şeyh Safi Buyruklarından bir yazmaya göre SSeriat, Tarikat, Marifet ve Hakikat, talibe gerekli ve zorunlu şeylerdendir. Bazı sorulara verilen cevaplarda, Şeriatın Resulullah'ın sözü, Tarikatın Resullullah'ın fiilleri, Marifet ve Hakikatin ise Resulullah'in hâli olduğu ifade edilir. ${ }^{15} 1612$ tarihli Manisa Şeyh Safi Buyruğuna göre ise, Şeriat Hz. Muhammed'in sözü, Tarikat yolu, Marifet fiili, Hakikat ise hâlidir. ${ }^{16}$ Malatyalı Sadık Baba (1771-1837) da Dört Kapı'yı, "Hasan ile Hüseyin'in atasi" olan Hz. Muhammed'e bağlar. Ona göre Dört Kap1 Kırk Makam'ın merkezinde Hz. Muhammed vardır: "Hasan ile Hüseyin'in atası / Cümle evliyanın gerçek putası [nişangâh] / Dört Kapi'nın Kırk Makam'in ortası / Hakikat babinda dermanı gördüm". ${ }^{17}$ Amasyalı Fedayî Baba (1855-1940), Dört Kapı'y1 Hz. Muhammed’in kurduğunu ve bu süreci tamamlayanların Kırklara karışacağını söyler: "Ey Fedayî Ahmet açtı Şeriat / Tarikat, Marifet, Kurb-u Hakikat / Dört Kapı Kirk Makam kurdu tamamet / Kirklarin ceminde irfanı bildim”. ${ }^{18}$

Dört Kap1 için kullanılan bir diğer kaynak, Muhammed-Ali'dir. Alevilikte nübüvvet (peygamberlik) ve imamet (On İki İmam) inançlarının sembolik bir anlatımı olan Muhammed-Ali ifadesi, On İki İmam'i Hz. Muhammed'in ilahi varisi sayar. İmam Cafer Buyruğunun Malatya yazmasında yol ve erkân olarak bahsedilen Dört Kapı'nın (Şeriat, Tarikat, Marifet, Hakikat) Muhammed-Ali'den kaldığ

12 Özmen, Alevi-Bektaşi Şiirleri Antolojisi, 3/207.

13 Abdurrahman Güzel, Hacı Bektaş Veli El Kitabı, (Ankara: Akçağ Yayınları, 2011), 424.

14 Buyruk, 70.

15 Erkânnâme-1, nşr. Kaplan, (Ankara, Türkiye Diyanet Vakfı Yayınları, 2007), 133.

16 Bisati, Şeyh Safi Buyruğu, 18, 91.

17 Özmen, Alevi-Bektaşi Şiirleri Antolojisi, 3/381.

18 Özmen, Alevi-Bektaşi Şiirleri Antolojisi, 4/495. 
belirtilir. ${ }^{19}$ İmam Cafer Buyruğunun İzmir yazmasında Dört Kapının kaynağ1 "Muhammed Ali"ye, başka bir yerde ise Hz. Ali'nin bir buyruğuna dayandırılır. Bu metinlerin ilkine göre; "O zamandan bu güne kadar, Şeriat, Tarikat, Marifet, Hakikat (...) Muhammed Ali'den kaldı". ${ }^{20}$ İkinci metinde ise şöyle der: "Hazreti Ali Emirülmüminin buyurmuş ki; Seriatın, Tarikatın ve Marifetin ve Hakikatin ahvallerin [hâller, durumlar] beyan eder ki talip olan tutmak gerektir." 1

Hoca Ahmet Yesevî de, Fakrnâme adlı eserinde Dört Kapı kavraminı Hz. Ali'nin bir buyruğuna dayandırır. Yesevînnin bildirdiğine göre; "Hazret-i Ali'den, Allah ondan razı olsun, rivayet ederler ki dervişlik makamı kırktır. Eğer (bir derviş) bilip (buna göre) amel etse, dervişliği temiz olur ve eğer bilmese ve ögrenmese, dervişlik makamı ona haram olur ve (o kişi) cahildir. O Kırk Makam'in onu SSeriat makaminda ve onu Tarikat makaminda ve onu Marifet makaminda ve onu Hakikat makamindadır". ${ }^{22}$

Diyarbakırlı Ahû Baba (17. yüzyıl), Dört Kapı'nın inceliklerini anlattığ1 bir nefesinde Hakikati dolayısıyla Dört Kapı'yı Şah-1 Merdan'dan yani Hz. Ali'den aldığını söyler: "Esrarı Hakikat gizli yerdedir / Hakikati Şah-ı Merdan'dan aldım”. ${ }^{23}$ Eskişehirli Gencî Abdal (19. yüzyıl) bir şehre benzettiği Dört Kapı'nın mimarını Hz. Ali olarak tanıtır: "Dört Kapı içinde bir şehir gördüm / Mimarımız Şah-ı Merdan Ali'dir / Açılmış kapısı, içeri girdim / Pazarımız Şah-ı Merdan Ali'dir". ${ }^{24}$

İmam Cafer Buyruklarının Maraş yazmasında İmam Cafer Sadık'ın, Dört Kapı'yı isimleriyle andığı bildirilir. Metne göre, "İmam Cafer Sadık aleyhisselam", bir "pir"in kâmil olması gerektiğini söyler. Pirin kâmil olmasını ise kimi şartlara bağlar: 1) Şeriat, Tarikat, Marifet ve Hakikati bilmesi, 2) Bunların nerden geldiğini ve neden olduğunu bilmesi, 3) Bunların aslının, adının, odunun [ateşinin], mayasının, tövbesinin, farzının, sünnetinin, işlemesinin ne olduğunu bilmesi, 4) Şeriat kaçtır, Tarikat kaçtır, Marifet kaçtır ve Hakikat kaçtır sorularının cevabını bilmesi, 5) Şeriat ne ile tamam olur ve Hakikat ne ile tamam olur sorularının cevabını bilmesi. Eğer bu bilgilere sahip değilse o kişi Hakikate ulaşamaz. Pirlik yapması da

\footnotetext{
19 Buyruk, 204.

20 Buyruk, 12.

21 Buyruk, 74.

22 Kemal Eraslan, Yesevî’nin Fakr-nâmesi, (Ankara: Hoca Ahmet Yesevî Uluslararası Türk-Kazak Üniversitesi Yayınları, 2016), 52.

23 Özmen, Alevi-Bektaşi Şiirleri Antolojisi, 3/62.

${ }^{24}$ M. Tevfik Oytan, Bektaşiliğin İçyüzü: Dibi, Köşesi, Yüzü ve Astarn Nedir?, (İstanbul: İstanbul Maarif Kitaphanesi ve Matbaas1, 1956), 1/87.
} 
uygun değildir. ${ }^{25}$ Urum Abdallarından Seher Abdal (16-17. Yüzyı1lar) da, "İmam-ı Cafer-i kan-ı Hakikat / Anın fermanıdır ilm-i Şeriat / Ki nutkundan zuhur etti Tarikat / Hem oldur menba'-i Hakikat"26 diyerek Dört Kapı'yı İmam Cafer Sadık'a bağlar.

Hacı Bektaş Veli'ye nispet edilen Fevaid adlı eserde Dört Kap1 programının kaynağı olarak Hoca Ahmet Yesevî gösterilir. Hacı Bektaş Veli, bu programı Hoca Ahmet Yesevî'den öğrenmiştir: "Ariflerin sultanı ve gerçeği bilenlerin önderi, önceki ve sonraki sırları keşfeden Hâce Ahmet Yesevî, sirn kutlu olsun, sözlerinden: İrşat için Hacı Bektaş Veli'ye buyurmuştur ki: 'Bütün yol sahipleri Dört Kapı, Kırk Makam'ı ve içindekileri bilmesi gerekir. On makamı Şeriatta, on makamı Tarikatta, on makamı Marifette, on makamı Hakikatte". ${ }^{27}$

Özetle, Aleviliğin iç metinlerinde Dört Kapı kavramı Allah'tan Cebrail vasitasiyla Hz. Muhammed'e, Hz. Muhammed'den Hz. Ali'ye, $\mathrm{Hz}$. Ali'den evlatları Hz. Hasan ile Hz. Hüseyin'e, On İki İmam'dan Hoca Ahmet Yesevîye ve Safevi tarikatının kurucusu Şeyh Safi'ye, Hoca Ahmet Yesevî'den de Hacı Bektaş Veli'ye intikal etmiştir. Bazı ariflerin Dört Kapı'yı doğrudan doğruya $\mathrm{Hz}$. Muhammed veya $\mathrm{Hz}$. Ali'den öğrenmesini ifade etmesi ise irfan yolunda sıklıkla görülen batın yoluyla eğitim şeklinde yorumlanabilir. Ne ifade edilmek istenirse edilsin, sonuç olarak Alevilik yolunda Dört Kapı programının kaynağ1 Kur'an-1 Kerim ve Hz. Muhammed'dir. Daha sonra On İki İmam'a intikal eden bu miras, bütün Alevi tarihine ve toplumuna yayılmıştır.

\subsection{Dört Kapının Temel Özellikleri}

Aleviliğin yazılı kaynaklarını dikkatle incelediğimizde Dört Kapı, kimi temel özellikleri ile ön plana çıkar. Bu temel özellikleri aşağ1daki gibi ifade etmek mümkündür.

1) Dört Kapı bir eğitim programıdır.

2) Dört Kapı bir erginleme sürecidir.

3) Dört Kapı'dan hiçbiri eksik olmamalıdır.

4) Dört Kapı'da disiplin şarttır.

5) Her kapı için ayrı bir strateji uygulanır.

6) Şeriat zahir, diğerleri batındır.

7) Dört Kapı'yı tamamlayan veli olur.

\footnotetext{
25 Buyruk, 161-162.

26 Özmen, Alevi-Bektaşi Şiirleri Antolojisi, 2/495.

27 Güzel, Hacı Bektaş Veli El Kitabı, 426.
} 


\subsubsection{Dört Kap1 Eğitim Programıdır}

Ülkemizdeki Kızılbaş sürekleriyle Bektaşi Tarikatında iyi bilinen ve çokça dillendirilen ayrıca yazılı kaynaklarda sayısız referansa sahip olan Dört Kap1 kavramı, Aleviliğin eğitim sistemini oluşturan ana ögelerden biridir. Bir eğitim sisteminin dört ana ögeden oluştuğu ve bu ögelerin öğrenci, öğretmen, program (müfredat) ve okul olduğu bilinen bir konudur. ${ }^{28}$ Kizılbaşlık ve Bektaşilikte de bu unsurların bir arada bulunduğu bir eğitim sistemi vardır. Öğrenciler Bektaşilikte (Babağan kolu) derviş, Kızılbaşlikta ise talip isimlerini alırlar. Bektaşilikte baba, halifebaba, dedebaba; Kızılbaşlıkta rehber, baba, dede, pir, mürşit gibi unvanlara sahip kişilerin açıkça tanımlanmıș öğretmenlik ve yol göstericilik görevleri vardır. Eğitim kurumlarının yerini Bektaşilikte dergâhlar, Kızılbaşlıkta ise ocaklar ve bazı ocakların kurumsal ifadesi olan dergâhlar ${ }^{29}$ alır. Müfredata gelince hem Kızılbaşlıkta ve hem de Bektaşilikte Dört Kap1 adıyla anılan geniş bir eğitim programının hayata geçirilmesi esastır. Esasen Kızılbaşlıkta ve Bektaşilikte eğitim devam eden bir süreçtir. Bektaşilikte dedebaba, Kızılbaşlıkta ise mürşit oluncaya kadar kişinin yetkili kişiler tarafından eğitimi devam eder. Yani kişinin baba, halifebaba, rehber, dede vb. olup bir nevi öğretmenlik yapması onların eğitiminin sonlandığı anlamına gelmez. Bütün bu kişilerin eğitimi, Dört Kap1 programı içinde bağlı oldukları üst derecedeki kişiler tarafından sürdürülür.

Dört Kap1, yazılı kaynaklarda doğrudan bir eğitim programı olarak geçmez ama yapılan açıklamalardan onun bir eğitim programı olduğu açıkça anlaşılır. Mesela İmam Cafer Buyruklarının Malatya yazmasında yer alan bir anlatıda Aleviliğin eğitim sistemi çıplak gözlerle görülebilecek netliktedir. Metne göre, Şeriatın şartlarını yerine getiren ve Tarikat ehli olmak isteyen kişi sırayla kapıcıya, gözcüye ve tarikçiye varır, daha sonra mürşidin huzuruna çıkar. Mürşit, Tarikat adayına, "Bu meydan Ali meydanıdır. Bu meydana girenin başı top, gerdanı kurban gerektir" diye nasihat eder. Eğer Tarikata girmek isteyen aday, kararlılığını ifade ederse talip olarak Tarikata kabul edilir. Ardından uygun görülen bir sufiye terbiye edilmesi için teslim edilir. Başlangıçtan sona kadar Dört Kapı'nın Kırk Makam'ın ameli öğretilir. ${ }^{30}$ Yukarıdaki aktarımda bir eğitim sisteminde olmas1 gereken dört ana unsur vardır. Bu eğitim sisteminin öğrencisi talip, öğretmeni yetkin bir sufi daha sonra mürşit,

${ }^{28}$ Münire Erden, Eğitim Bilimlerine Giriş, (Ankara: Arkadaş Yayınları, 2011), 11 26.

29 Cenksu Üçer, "Alevî Nitelemeli Ocak/Gruplara Ait Tekke, Zâviye Ve Dergâhlardaki Cami ve Mescidler”, 271-307.

30 Buyruk, 208-209. 
eğitimin yapıldığı yer dergâh, eğitim programının adı Dört Kapı Kırk Makam'dır. Şeyh Safi Buyruklarından birinde mürebbinin talip üzerindeki eğiticilik görevine ve hakkına vurgu yapılır. ${ }^{31}$

Alevi âşıkları da Dört Kapı'nın eğitim programı olduğuna atıf yapmışlardır. Alevi edebiyatının kudretli âşıklarından Hatayi (16. yüzyıl) bir şiirinde pirlerin eğitici, taliplerin öğrenci ve Dört Kapı'nın da müfredat olduğunu söyler: "Pir odur ki pir yurdunda otura / Talibin noksanını yetire / Teselli verüben yola getire / Eriştire Dört Kapi'nın hepsine". ${ }^{32}$ Bektassi âşıklarından Kâtib (17-18. yüzyıl), Dört Kapı'yı anlattığı bir şiirinde âşıklık davasında olanların bir kâmil mürşitten ders alması gerektiğini söyler. ${ }^{33}$ "Sersem Pervane" mahlasıyla da nefesler söyleyen Âş1k Sidkı Baba (1865-1928), Dört Kapı'nın hedeflerine bir nevi eğitimci yardımıyla ulașılabileceğini vurgular: "Dört Kapının Kırk Makam’ın manasın / Bir kâmil mürşide sor da bak, sor da". ${ }^{34}$

Özetle, Alevilik, bir eğitim sisteminde olması gereken bütün bileşenlere sahiptir ve bu eğitim sisteminin programı Dört Kapı'dır. Bir eğitim programı olarak tasarlanan Dört Kap1, hem bireysel ve hem de toplumsal eğitimin temelini oluşturur. Eğitimciler eliyle dergâhlarda ve ocaklarda hayata geçirilir.

\subsubsection{Dört Kap1 Bir Erginleme Sürecidir}

Kaynaklarda Dört Kapı kavramının dikkat çeken özelliklerinden biri de bir süreç, yol veya seyir olmasıdır. Başı ve sonu açıkça tanimlanan bu yolculuk, ssehadet getirmekle başlar ve Hakk'la hak olmaya kadar devam eder. İnsanı ham halinden alarak aşama aşama geliştiren Dört Kapı'nın ana hedefi Hakk'a vasıl olmaktır; O'na kavuşmak yani vuslata ermektir.

İmam Cafer Buyruklarının Hacıbektaş-1 yazmasında Dört Kap1 Kırk Makam, "Hakk'a doğru giden" bir süreç olarak tanımlanır. ${ }^{35}$ İmam Cafer Buyruklarının İzmir yazmasında, "yola varmak" için Şeriat, Tarikat, Marifet ve sırr-1 Hakikatin lazım olduğu belirtilir. ${ }^{36}$ Şeyh Safi Buyruklarından birine göre, "Muhammed Ali'nin yolu SSeriat, Tarikat, Marifet, Hakikat"tir". 37 Yol erenlerinden Muhyiddin Abdal'a (16. yüzy1l) göre ise, Şeriat, Tarikat, Marifet ve Hakikati bi-

\footnotetext{
31 Erkânnâme-1, 205.

32 Özmen, Alevi-Bektaşi Şiirleri Antolojisi, 2/148.

33 Özmen, Alevi-Bektaşi Şiirleri Antolojisi, 3/272.

34 Özmen, Alevi-Bektaşi Şiirleri Antolojisi, 4/566.

35 Buyruk, 219.

36 Buyruk, 70.

37 Erkânnâme-1, 141.
} 
len kişiler, "doğru yola varan erenler"dir. ${ }^{38}$ Genci Abdal (19. yüzy1l), "Dört Kapi'dan Kirk Makam'a yol verir / Hakikatte özge hâl eyler seni”39 diyerek Dört Kapı'nın yol yani süreç olma özelliğine gönderme yapar.

1612 tarihli Manisa Şeyh Safi Buyruğunda hâl ehlinin makam1nın dört olduğu ifade edilir ve her makamda bulunan kişilerin özellikleri sıralanır. Buna göre, Şeriatın avam [bilgin olmayan sıradan halk] için, Tarikatın iptida [işin başlangıcında olanlar] için, Marifetin münteha [işin sonunda olanlar] için, Hakikatin ise intiha [en sona ulaşanlar] için olduğu söylenir. ${ }^{40} \mathrm{Bu}$ nedenle kişi hangi kap1daysa o kişiyle, bulunduğu kapının ilmiyle konuşulmalıdır. ${ }^{41}$ İmam Cafer Sadık Buyruğunun Hacıbektaș-2 yazmasında kișilerle derecelerine göre konuşulması gerektiği ifade edilir. Derviş hırkasını giyenler hem SSeriat, hem Tarikat, hem Marifet ve hem de Hakikat ilmini bilmelidir. Ancak Şeriattan sorulursa Şeriat ilminden, Tarikattan sorulursa Tarikat ilminden, Marifetten sorulursa Marifet ilminden ve Hakikatten sorulursa Hakikat ilminden cevap verilmelidir. ${ }^{42}$

Hak âş1klarından Kâtibî (17-18. yüzyı1), Dört Kapı'nın bir süreç olduğunu ve tüm sürecin insanı Hakikate ulaştırdığını şöyle anlatır: "Dört harfin evveli Şeriat kamu / İkinci makamı Tarikat babı / Hakikate gider bunlarin hepi / Marifete girip Hakk'a yettin mi?". ${ }^{43}$ Malatyalı Sadık Baba (1771-1837) da Dört Kapı'nın "yol” olduğunu, "Dört Kapı'dan Kirk Makam'a yol olsun"44 ve "Dört Kapı'yı Kirk Makam'ı yol eyler"45 misralariyla dillendirir.

Kul Hüseyin (16. yüzyıl) bir nefesinde Dört Kapı'nın bir süreç olduğunu ve menzillerinin bulunduğunu şöyle açıklar: "Evvel kapı Şeriattır girerler / Tarikatta gonca güller dererler / Canlar menziline anda ererler / Acep menziline erebildin mi? / ... / Şeriat dildedir Tarikat canda / Gönül dost evinde mihmandir anda / Bunca velilerin mekânı kande [nerde] / Hakikat elinde seyfi [kılıç] bildin mi?". 46

\footnotetext{
38 Bayram Durbilmez, Muhyiddin Abdal Divant (inceleme-tenkitli metin), (Doktora Tezi, Firat Üniversitesi, 1998), 124-127.

39 Oytan, Bektaşiliğin İçyüzü, 1/41.

40 Bisati, Şeyh Safi Buyruğu, 17, 18.

41 Bisati, Şeyh Safi Buyruğu, 91.

42 Buyruk, 243.

43 Özmen, Alevi-Bektaşi Şiirleri Antolojisi, 3/272.

44 Özmen, Alevi-Bektaşi Şiirleri Antolojisi, 3/396.

45 Özmen, Alevi-Bektaşi Şiirleri Antolojisi, 3/398.

46 Özmen, Alevi-Bektaşi Şiirleri Antolojisi, 2/343.
} 
Tarikata giren kişi için yerine getirilen uygulamalardan birinde Dört Kapı ehli için farklı hitaplar kullanılır. Bu hitapların farklı derecedeki kișileri ifade ettiği açıkça görülür. 1893 tarihli Hacı Kırzade Hüseyin Hüsnü Baba Erkânnâmesinde Tarikata giren kișinin verdiği selamda Şeriat ehlinden "erenler", Tarikat ehlinden "pirler", Marifet ehlinden "kâmiller", Hakikat ehlinden ise "şahlar" olarak bahsedilir.47 1895 tarihli Derviş Muhammed Erkânnâmesi48 ile 1936 tarihli bir Erkânnâme'de ${ }^{49}$ de aynı hitaplar kullanılır. Yol ehlinden Şahiya (16. yüzyıl), "Dört Kapı selamı"nı bir şiirinde şöyle anlatır: "Kurbanlar tiğlanup gülbank çekildi / Gaflet uykusundan uyana geldim / Dört Kapr sancağı anda dikildi / Üryan büryan olup meydana geldim / ... / Dört Kapı selamın verip aldılar / Pirin huzuruna çekip geldiler / Elele el Hakk'a olsun dediler / Henüz masum olup cihana geldim".50

Başka metinlerde ise Şeriatı tamamlayarak Tarikata girecek kişinin, Şeriat, Tarikat, Marifet ve Hakikat ehli kişileri ayrı ayrı selamlamakla yükümlü olduğu söylenir. Bu hitaplar, her kapıdaki kişilerin farklı menzillerde olduğunu gösterir. Tarikata giren kişinin söz konusu selamlaması şöyledir: "Esselamü aleyküm ya ehli Şeriat. Esselamü aleyküm ya ehli Tarikat. Esselamü aleyküm ya ehli Marifet. Esselamü aleyküm ya ehli Hakikat". ${ }^{51} 1629$ tarihli Seyyid Ali Hacı Turabi Ocağına ait şecere ile 1893 tarihli Hacı Kırzade Hüseyin Hüsnü Baba Erkânnâmesinde ${ }^{52}$ de aynı selamlama yapilır.

Otman Baba Velayetnâmesi'nde açıkça aşamalı bir durumdan bahsedilir. Buna göre kişi, velayet sahibi olmak için Hakikat kap1sında olmalıdır. Marifet kapısındaki kişi velayet makamına ulaşmış değildir. Çünkü Marifet kapısı ilim makamıdır. ${ }^{53}$

Eldeki bütün kaynaklar Dört Kapı'nın Şeriattan Hakikate giden bir süreç olduğunu itiraza mahal bırakmayacak şekilde göstermektedir. Adım adım, basamak basamak ilerlenen bu süreç, birbirini

47 Cem Erdem-Ersoy Topuzkanamış, "Hac1 Kırzade Hüseyin Hüsnü Baba Erkânnâmesi”, Alevilik-Bektaşilik Araştırmalarn Dergisi, 10 (2014): 125.

48 Dursun Gümüşoğlu-Rıza Yıldırım, Bir Bektaşi Erkânnâmesi: 1313 Tarihli Bir Erkânnâme Metni, (İstanbul, Horasan Yayınları, 2006), 22.

49 Yunus Koçak, "Arnavutluk Devlet Arşivlerinde Bulunan Türkçe Yazma Eserler/Erkânnâme: 2", Türk Kültürü ve Hacı Bektaş Veli Araştırma Dergisi, 33 (2005): 71-144.

50 Özmen, Alevi-Bektaşi Şiirleri Antolojisi, 2/192.

${ }^{51}$ Buyruk, 248.

52 Erdem- Topuzkanamış, "Hacı Kırzade Hüseyin Hüsnü Baba Erkânnâmesi", 125.

53 Otman Baba Velâyetnâmesi Tenkitli Metin, nşr. Filiz Kılıç v.dğr. (Ankara: Grafiker Yayınc1lık, 2007), 43. 
takip eden aşamalardan ibarettir. Bu nedenle öngörülen sıralamaya uymak ve önceliği buna göre belirmek son derece önemlidir. Yani kişi, Şeriatı yerine getirmeden Tarikata giremez. Marifeti yerine getirmeden Hakikate varamaz.

\subsubsection{Dört Kapı'dan Hiç Biri Eksik Olmamalıdır}

Dört Kapı ile ilgili olarak dikkat çeken bir diğer husus bu kap1lardan birinin eksik olması halinde, kişinin istenilen hedefe ulaşamayacağıdır. Yani değil Dört Kapı'dan biri makamlardan biri bile eksik olsa, kişi kâmil insan olamaz. Öngörülen hedefe ulaşamaz.

Hacı Bektaş Veli'ye nispet edilen Makâlât kitabında Dört Kapı'nın ara basamaklarını ifade eden Kırk Makam'dan birinin bile eksik olması halinde Hakikatin tamam olmayacağı söylenir: "Eğer bu Kırk Makamin birisi eksik olursa Hakikat tamam olmaz zira eksik olur. Mesela birisi diliyle iman getirse ve gönlüyle inanmasa ve zekâtını vermese yahut Tanrinin hükümlerinden birini inkâr etse yahut $\mathrm{Mu}$ hammed Mustafa'yı inkâr etse yahut evlatlarindan birine haksiz dese, işlediği bütün amelleri boşa gider. Allah Teâlâ şöyle buyurmuştur: "Onu saçılmış zerreler haline getiririz (değersiz kılarız) (Furkan, 25 / 23). SSimdi ey azizim! Kırk makamdan birisinin eksik olmamasi gerekir. Zira makamlarda eksik birakılan bir şey yok". ${ }^{54}$

İmam Cafer Sadık Buyruğunun İzmir yazmasında Dört Kapı'nın bütünlüğüne vurgu yapılır. Dördünün birbirine "ayan" [açık] ve hepsinin "bir" olduğu ifade edilir. 55 İmam Cafer Buyruğunun Hac1bektaş-2 yazmasında kişinin Dört Kapı'dan hepsine vakıf olması ve hangisinden sorulursa sorulsun cevap vermesi gerektiği ifade edilir. ${ }^{56} 1612$ tarihli Manisa Şeyh Safi Buyruğunda da aynı hususlar, benzer ifadelerle yer alır. ${ }^{57}$ Balım Sultan olarak ünlenen Hacı Bektaş Veli Dergâhı postnişinlerinden Hızır Bali (1473 - 1516) de "arif" olmayı Dört Kapı'nın tamamına uymakla eşitler: "Evvel baştan Muhammed'e salavat / Arif isen bu manayı ver imdi / Şeriattır Tarikattır, Marifet / Hakikatten bize haber ver imdi”. 58

Yol ehlinden Muhyiddin Abdal (16. yüzyıl) eserlerinde Dört Kapı'nın birlikteliğine vurgu yapar. Ona göre, bunlardan biri olmadan sonuca ulaşmak mümkün değildir: "Şeriat şartını bilen, Tarikat ter-

\footnotetext{
${ }^{54}$ Hünkâr Hacı Bektaş Veli, Makâlât, nşr. Ali Yılmaz-Mehmet Akkuş-Ali Öztürk, (Ankara: Türkiye Diyanet Vakfı Yayınları, 2015), 81-82.

55 Buyruk, 29.

56 Buyruk, 243.

57 Bisati, Şeyh Safi Buyruğu, 91.

58 Özmen, Alevi-Bektaşi Şiirleri Antolojisi, 2/21.
} 
kine giren, Marifetten delil alan ve Hakikatten yolu olan kimsenin müșkülü hallolur”. ${ }^{59}$

Seyyid Gazi dervişlerinden Yetimî (16. yüzyı1), Bektaşileri övdüğü bir eserinde, Bektaşi olan kişinin Dört Kapı'nın tamamına birden sahip olması gerektiğini söyler: "Hem Şeriattan haberdar hem Tarikat ehlidir / Marifet babinda tekmil hem Hakikat ehlidir (...) Hact Bektaş-ı Veli Hünkârı var Bektaşi'nin”. ${ }^{60}$

Hacı Bektaş Veli evlatlarından Feyzullah Çelebi'nin kızı Güzide Ana (18. yüzyıl), bütün kapıların bir arada olması halinde gerçeklere ulaş1labileceğini söyler: "Haberdar ol Şeriattan / Yol bulasın Tarikattan / Marifetten Hakikatten / Eriş gerçek söze doğru". ${ }^{61}$

Yol ehlinden Malatyalı Sadık Baba (1771-1837) da Dört Kapı'nın birliğine ve hiç birinin eksik kalmaması gerektiğine dair bilgiyi tekrarlar: "SSeriatı hak bilmeyen / Tarikata kul olmayan / Marifet ehli olmayan / Hakikatte hâli bilmez."62

Hak âş1klarından Arguvanlı Âşıkî (ölm. 1824) ise bir şiirinde "Şeriatın şartlarını yitirme (...) Hakikat içinde halden ayıptı" diyerek Hakikate ulaşmak için diğer kapılarda da kararlı olmak gerektiğini söyler. ${ }^{63}$

Şeyh Safi Buyruklarından birinde Dört Kapı'nın birlikteliğine vurgu yapılır. Dört Kapı'dan biri eksik olan kişiye, uçsa bile, inanılmamas1 gerektiği kesin bir dille vurgulanır: "Eğer talip, bu dört şeyi (Şeriat, Tarikat, Marifet, Hakikat) terk etmezse gerçek anlamda Hakikat ehli olur. Şeriatı ve Tarikatı sağlam olur. Müslümanlık amelini işlemiş olur. Nefsini kolaylıkla dizginleyebilir. Rıza makaminda olur. Bu nedenle böyle bir kişi Yüce Allah'in farzlarını ve $\mathrm{Hz}$. Muhammed'in sünnetlerini asla eksik yapmamall. Bu söylenenleri eksik yapanlar yalancı olurlar ve böyle kimseler gökte de uçsalar bunlara inanmamak gerek". ${ }^{64}$

Dört Kap1 programı, süreklilik arz eden ve yeni bilgilerin eskisini kaldırmadığı bir düşünce biçimi üzerine bina edilmiştir. Ulaşılan menzildeki yeni bilgi ve uygulamalar eskisinin üzerine konulur ve geçmişin birikimi reddedilmez.

\footnotetext{
59 Durbilmez, Muhyiddin Abdal Divant, 124-127.

60 Özmen, Alevi-Bektaşi Şiirleri Antolojisi, 2/519.

61 Özmen, Alevi-Bektaşi Şiirleri Antolojisi, 3/220.

62 Özmen, Alevi-Bektaşi Şiirleri Antolojisi, 3/384.

63 Özmen, Alevi-Bektaşi Şiirleri Antolojisi, 4/55.

${ }^{64}$ Erkânnâme-1, 133-134.
} 


\subsubsection{Dört Kapı'da Disiplin Şarttır}

Eğitim, disiplinsiz olmaz. Öngörülen hedeflere ulaşmak için disiplinli olmak şarttır. Özellikle eğitici konumunda olanların sözlerine uymak ve onların rızalarından çıkmamak, kaynaklarda başarı için 1srarla vurgulanır.

Şeyh Safi Buyruklarından bir yazma metne göre, yola giren derviş veya talip, evliyanın emrini yerine getirip, söylediğini yapmalıdır. Böyle yapmayan dervişler ve talipler, sözünden dönüp ahdine vefa göstermeyenlerdir. Mürtet ve sürgün olan böyle kişileri cemden dişlamak gerekir. Tarikatta, Marifette ve Hakikatte böyle kişilerle konuşmamak şarttır. Sadece bu kişiler değil, bunlarla sohbet edip, bunlara lokma yedirenler de yol bozmuss zalimlerden olurlar. ${ }^{65} \mathrm{Bu}$ yaptırımlarla Tarikattaki yozlaşmanın önüne geçmek ve iç disiplinin sağlanması hedeflenir. Bu uğurda başka yaptırımlar da kaynaklarda dikkati çeker. SSeyh Safi Buyruklarından birine göre, bir talip ikrar verip yola girdikten sonra Dört Kapı'nın tamamını kabul etmelidir. Üç kişi bir araya gelip sohbet ettiğinde içlerinden biri, mesela Marifet kapısından bir hususu kabul etmediğini ifade etse ve diğerleri de buna sessiz kalsa üçü de yoldan çıkar. Üçü de zalim olur. Sohbetleri ve orada yedikleri yemek haram olur. Diğer ikisinin, "Tarikat içinde sen günahkârsın" deyip, o kişiyi uyarmaları gerekir. ${ }^{66}$

Pir Sultan Abdal (16. yüzy1l), bir şiirinde yolun samimiyetle aşılacağına ve riya kabul etmeyeceğine vurgu yapar: "Bu yolun içinde riya tutana / Sürün gitsin Dört Kapı'da yol olmaz". 67 Yine Pir Sultan Abdal, bir başka şiirinde yolu aşabilecek kişilerin vasıflarını sayar. $\mathrm{Bu}$ vasiflar yola boyun vermek, Dört Kapı'yı bilmek, halden anlamak, Hakikati dinlemek, yoldan ayrılmamak, yol üzerinde durmak, işi Mevla'ya salmak, izzetli olmak, selam vermek, gönüllere girmek, dünya davasını bırakmak, Hakk'a sevdalanmak, öz nefsini doğrulamak, şeytanını öldürmek, velilere hürmet etmek, yolun sırrını sormak, hal ehli olmak gibi hususlardır. ${ }^{68}$

Elbette hata işleyen ve hatasından samimi olarak pişmanlık duyanlar için tövbe kapısı her zaman açıktır. Çünkü hatasız kul olmaz. Şeyh Safi Buyruklarından birine göre Marifet sahibi kardeşiyle Hakikat yolunu gözleyen, evliya izinden giden, kendine sürekli eleştirel gözle bakan bir Tarikat ehli, bir günah işlese ve isslediği günahını bilerek insaf makamına geçip "mürüvvet" dese o kişiye bağış-

\footnotetext{
65 Erkânnâme-1, 158.

66 Şeyh Safi Buyruğu, 91.

67 Özmen, Alevi-Bektaşi Şiirleri Antolojisi, 2/249.

68 Özmen, Alevi-Bektaşi Şiirleri Antolojisi, 2/260.
} 
lanma yolu açılır. Cemiyet gönül birliğiyle ona helallik verip gülbank okur, o kişi de yüzünü yere koyup niyaz eder. Böylece günah işleyen kiși, günahından arınıp bağışlanır. Temizlenir ve kalbi temiz insaf sahibi kişilerden olur. ${ }^{69}$

Şeyh Safi Buyruklarından birinde Dört Kapı'da hedeflenen amaçlara ulaşmak yani insan-1 kâmil olmak için iki şey çok önemli görülür. Bunlardan birincisi, kişinin az yemesi ve az uyumasıdır. İkincisi ise yola giren kişinin niyetinin temiz, dürüst ve sadık olmasıdır. ${ }^{70}$

Sadece eğitim için değil, bütün iş ve işlemlerde disiplin şarttır. Disiplin olmadan hiçbir konuda başarılı olunamayacağı gibi, Dört Kapı'da da başarılı olmak mümkün değildir. Sadece kişinin disiplinli olması yeterli değildir, onun disiplinini bozacak ortamların da yok edilmesi gerekir. Kişinin ilerlemesini engelleyecek unsurlar da ortadan kaldırılmalıdır. Başarı yolundaki bir diğer husus, samimiyettir. Disiplin kadar samimiyet de önemlidir. Çünkü kişi samimi olmazsa, hiçbir menzili aşamaz. İşin içine riya ve gösteriş girer. Böylece işin büyüsü bozulur.

\subsubsection{Her Kapı İçin Ayrı Strateji Uygulanır}

Dört Kapı'nın hedeflerine ulaşmak için, her kapıda farklı stratejiler uygulamak gerekir. Çünkü her kapının özelliği ve içeriği farkl1dır. İmam Cafer Buyruklarının Hacıbektaş-2 yazmasında mürşit, emanet olarak şu öğüdü bırakır: "Şeriatta muhkem [sağlam] ol, Tarikatta haberdar [bilgili] ol, Marifette payidar [kalıcl] ol, Hakikatte sabitkadem [devamlı, sadık] ol”.71 1936 tarihli bir Erkânnâmede mürşidin bıraktığı emanet benzer bir ögüttür: "Şeriatta sağlam ol, Tarikatta hayırlı ol, Marifette üstün ol, Hakikatte devamlı ol."72 İmam Cafer Buyruklarının İzmir yazmasında kişinin Şeriatta kâhil [ergin, yetişkin], Tarikatta haberdar [bilgili], Marifette agâh [bir şeyin sırr1na ulaşmış] Hakikatte payimal [sürekli, ebedi] olması gerektiği vurgulanır. ${ }^{73}$ Kırıkkaleli Hasan Dede (ölm. 1603) de bir mısrainda Hakikatte süreklilikten bahseder: "Her zaman kalbinde Hakikat gerek". ${ }^{74}$

Özetle kişinin Dört Kapı yolunda ilerlemesi için Şeriatta sağlam durmas1 ve ergin olmas1, Tarikatta bilgili ve hayırlı olmas1, Marifette

\footnotetext{
69 Şeyh Safi Buyruğu, 344-345.

70 Şeyh Safi Buyruğu, 91.

71 Buyruk, 249.

72 Koçak, "Erkânnâme: 2", 71-144.

73 Buyruk, 75.

74 Özmen, Alevi-Bektaşi Şiirleri Antolojisi, 3/27.
} 
agâh, üstün ve kalıcı olması, Hakikatte ise devamlı, sadık ve sürekli olmasi temel strateji olarak tavsiye edilmisstir.

\subsection{6. Şeriat Zahir, Diğerleri Batındır}

Dört Kapı hakkında dikkat çeken bir diğer husus, Şeriatın zahir, diğerlerinin ise sır veya batın olduğudur. Dini ve Şeriatı getiren $\mathrm{Hz}$. Muhammed'dir. Bu zahirdir yani zahir bilgisini esas alır. Bütün insanlığı kapsadığ için Şeriat, Hz. Muhammed'le anılır. Elbette Dört Kapi'nın tamamının sahibi Hz. Muhammed'dir. Hz. Ali, peygamber olmadığı için Şeriat sahibi değildir ama velayet mülkünün sultanı olarak diğer kapılara sahiptir. Bu nedenle Şeriat Hz. Muhammed ile öteki kapılar ise Hz. Ali ile anılır. 1612 tarihli Manisa Şeyh Safi Buyruğuna göre, "Şeriat Muhammed'in, Tarikat Ali'nindir". 75 İmam Cafer Buyruklarının Maraş yazmasinda, "Muhammed Mustafa ve Aliyyel Murtaza cümleye rahmet geldiler, dini zahir eylediler. Erkân koydular. SSeriat zahir oldu. Tarikat ve Hakikat sir oldu. Şeriat Muhammed'in oldu. Tarikat ve Hakikat Ali'nin şanına geldi"76 denilerek aynı hususa vurgu yapilir.

Şeyh Safi Buyruklarından birinde İslâm ile iman arasındaki kategorik farklılığa dikkat çekilir. Bir kişi "Allah'tan başka Tanr yoktur ve Muhammed Allah'in elçisidir" sözünü söyler ancak anlamını bilmezse ve anlamı üzerinde düşünmezse Müslümanlığı kabul olmaz. Tevhid kelimesini diliyle söyleyip kalbiyle inanmasa o zaman da imanı kabul olmaz. Bu bağlamda Şeriat Hz. Muhammed'in, Tarikat Hz. Ali'nindir ve bunlar birbirinden ayrı değildir. ${ }^{77}$ Yani burada iman, İslâm'ın bir üst aşaması olarak gösterilmiştir. Şehadet getirip bunun anlamına vakıf olanlar Müslüman olur. Allah'a gönülden bağlanarak Hz. Muhammed'i, Hz. Ali'nin tanıttığ gibi seven ve takip edenler ise mümin olur. Otman Baba Velayetnâmesinde yer alan bir şiirde, Dört Kapı'nın Kırk Makam'ı olduğu, Şeriatla Tarikatın bir olduğu, Marifetle Hakikatin de bunlarda sır olduğu ifade edilir. ${ }^{78}$

İslâm ile iman, Müslümanlık ile müminlik arasındaki kategorik farka vurgu yapılması, Şeriatın zahir, diğerlerinin batın yani sır olarak ifade edilmesi son derece önemlidir. Çünkü Müslümanlık, zahire göre anlaş1lır. İman ise kalpte yeşeren inançtır, içsel bir duyguyu ifade eder. Doğal olarak iman batınla anlaş1lır. Şeriatın sahibi $\mathrm{Hz}$. Muhammed, velayetin sahibi ise $\mathrm{Hz}$. Ali'dir. Bu bağlamda Bolulu Âş1k Dertli'nin (1772- 1845), "Biz güruha sorsalar ey kavm siz

\footnotetext{
75 Bisati, Şeyh Safi Buyruğu, 83.

76 Buyruk, 161.

77 Şeyh Safi Buyruğu, 417.

78 Yunus Yalçın, Türk Edebiyatında Velâyetnâmeler ve Otman Baba Velâyetnâmesi, (Yüksek Lisans Tezi, Erciyes Üniversitesi, 2007), 321.
} 
kimlersiniz / Tabi-i Şah-ı Velayeti Murteza derler bize"79 misrainda $\mathrm{Hz}$. Ali'yi velayet yani velilik makamının şahı olarak göstermesi daha da anlam kazanır. Çünkü Hz. Muhammed nübüvvet makamının şahı, Hz. Ali ise velayet makamının şahıdır.

\subsubsection{Dört Kap1'yı Tamamlayan Evliya Olur}

Dört Kapı programını hayata geçiren kişi velilik makamına erer, evliya olur. Şeriat, Tarikat, Marifet ve Hakikat bilgisine sahip kişi velayet makamına ulaşır. İmam Cafer Sadık Buyruğunun Hacıbektaş-1 yazmasında, Hakikat kapısına ulaşan kişinin evliya makaminda olduğu bildirilir. 80

Makâlât'ın başında eserin müellifi Hacı Bektaș Veli tanıtılırken, “... S.eriat terbiye ve bilgisiyle dolu, Marifet ve Hakikat hazinesi, Tarikat ehlinin makami, Şeriat kavminin müftüsü..."81 denir. Böylece onun veliliği Dört Kapı'yı tamamlamasına bağlanır. Otman Baba'nın (15. yüzyıl) hayatını anlatan Otman Baba Velayetnâmesi'nde de kișinin evliyalığı, kutbulaktablığı [kutupların baş1, büyükler büyügü] ve velayet sahibi olması yine Dört Kapı ile ilişkilendirilir. ${ }^{2}$ Demir Baba'nın (16. yüzyıl) hayatını ve kerametlerini anlatan Demir Baba Velayetnâmesi'nde, "evliyalık taslayan" "Timur Baba"ya Dört Kapı'sının tamam olup olmadığı sorulur. ${ }^{83}$ Yani burada evliyalık makamına ulaşmak, yine Dört Kapı'nın tamam olmasıyla ölçülür.

Özetle, Dört Kapı ile hedeflenen yer, evliyalık makamıdır. Dört Kapı'yı samimiyetle ve sağlam bir inançla tamam eden kişi evliyalık makamına ulaşır. Kimi metinlerde evliyalık, kimisinde velilik, kimisinde de velayet sahibi olmak sseklinde ifadesini bulan bu makam, kişinin kendi özünde Allah'1 bulmasıdır. O'na kavuşması, vuslata ermesidir. Kişi Hakikate ulaşınca hâl ehli olur, hâlden hâle girmez.

\subsection{Her Kapının Özellikleri Farklıdır}

Kaynaklarda Dört Kapı programı içinde ilerleyen kişiler, farklı özelliklerle ifade edilmiştir. Çünkü Dört Kapı sürekli ilerlemeyi ve tekâmül etmeyi öngörür. Bu farklı özellikleri aşağıdaki şekilde sıralamak mümkündür.

1) Her kapının selamı farklıdır.

\footnotetext{
79 Özmen, Alevi-Bektaşi Şiirleri Antolojisi, 4/364.

80 Buyruk, 230.

81 Güzel, Hacı Bektaş Veli El Kitabı, 293.

82 Otman Baba Velâyetnâmesi (Tenkitli Metin), 26, 102, 132, 133.

${ }^{83}$ Filiz Kılıç-Tuncay Bülbül, Demir Baba Velâyetnâmesi (İnceleme-Tenkitli Metin), (Ankara: Grafiker Yayınc1lık), 2011, 144.
} 
2) Her kapının babası farklıdır.

3) Her kapının kardeşi farklıdır.

4) Her kapının yemek usulü farklıdır.

5) Her kapının cünüplüğü farklıdır.

6) Her kapının abdesti farklıdir.

7) Her kapının günahı farklıdır.

8) Her kapının şahitleri farklıdır.

\subsubsection{Her Kapının Selamı Farklıdır}

İmam Cafer Buyruklarının İzmir yazmasında, her kapı için ayrı selam geldiği ifade edilir. Yani aynı kapıda, aynı derecede olan kişiler, aynı selamla selamlaşırlar. Şeriat ehline "Selam aleyküm", Tarikat ehline "Aşk olsun", Marifet ehline "Kuvvet olsun", Hakikat ehline "Hû" selamları gelmiştir. ${ }^{84}$ Hak erenlerinden Kemterî (ölm. 1896) de Dört Kap1'yı tamamlayıp Hakikate eren canları "Hû" diyerek selamlar: "Açıldı Hak kapısı / Sunuldu aşk dolusu / O Dört Kapı'dan içre / Girenin canina hû". 85

\subsubsection{Her Kapının Babası Farklıdır}

Yazılı kaynaklarda Dört Kapı'nın her birinde kişinin babası için farklı mecazlar kullanılır. İmam Cafer Buyruğunun Malatya yazmasında, bir kişinin Şeriat babasının öz babası, Tarikat babasının mürebbisi, Marifet babasının $\mathrm{Hz}$. Ali, Hakikat babasının ise $\mathrm{Hz}$. $\mathrm{Mu}-$ hammed olduğu ifade edilir. ${ }^{86}$

1936 tarihli bir Erkânnâmede benzer bir soruya verilen cevapta kişinin Şeriatta Âdemoğlu, Tarikatta yol oğlu, Marifette Muhammed Ali oğlu, Hakikatte ise yer ile gök oğlu olduğu söylenir. ${ }^{87}$

İmam Cafer Buyruğunun Hacıbektaş-2 yazmasında, "Ey derviş, talip misin, kalıp misın? Şeriatta kimin oğlusun? Tarikatta kimin oğlusun? Marifette kimin oğlusun? Hakikatte kimin oğlusun?" diye sorulur ve bu soruya, "Ey derviş talip oğluyum. Şeriatta Âdem Ata oğluyum. Tarikatta yol oğluyum. Marifette kemal oğluyum. Hakikatte yer anam gök atamdı»"88 şeklinde cevap verilir.

\footnotetext{
${ }^{84}$ Buyruk, 116.

85 Özmen, Alevi-Bektaşi Şiirleri Antolojisi, 4/628.

86 Buyruk, 211.

87 Koçak, "Erkânnâme: 2", 71-144.

88 Buyruk, 251.
} 
İmam Cafer Buyruğunun İzmir yazmasında soru sorulan kişi, yol oğlu olduğunu söyler. Ardından yolun Şeriat, Tarikat, Marifet ve sırr-1 Hakikatten oluştuğu bildirilir. 89

\subsubsection{Her Kapının Kardeşi Farklıdır}

İmam Cafer Buyruğunun Malatya yazmasında, Şeriatta, Tarikatta, Marifette ve Hakikatte kardeşinin kim olduğu ve biri kırk, kırkı bir edenin kim olduğu sorulur. Bu soruya verilen cevapta her biri tek tek açıklanır. Buna göre, "Allah bir, Resulü hak, Hazreti Ali on bir evladiyla hak" diyen kişi hem Şeriat hem Tarikat hem de Marifet kardeşi olur. "Hakk't insanda ve insanı Hakk'ta gören, ehl-i hak ile ve üstad-ı kâmil nazarında muhabbet eden ise Hakikat kardaşı olur." "Dört Kapi'nin hizmetini bilip işleyen ehlullah sahibi tasarruf nazarında kardaş olmakla Kırk Makam'da Kırklar ile kardaş olur."91 İmam Cafer Buyruğunun İzmir yazmasında ise Kırk Makam'da kırklar ile karındaş olunacağı ifade edilir. ${ }^{92}$

\subsubsection{Her Kapıda Yemek Farklıdır}

Hacı Bektaş Veli'ye nispet edilen Makâlât-1 Gaybiyye ve Kemalat-1 Ayniyye adlı eserde talibin yemesinin üç çeşit olduğu bildirilir. Bunlardan birincisi Şeriatta, ikincisi Tarikatta ve üçüncüsü Hakikattedir. Şeriatta yemek, yiyen kișinin rızık vereni yani Allah'ı çok anmasıdır. Böylece Mabuduna [Tanrı'sına] karşı itaatini yerine getirir. Tarikatta yemek, kişinin yemede ve içmede israf etmemesidir. Hakikatte yemek, yiyen ve içen kişinin Hakk'ı kendi zatında gözlemlemesidir. Talip bu makama erdiğinde Allah'tan başka hiçbir şeyin var olmadığını anlar. ${ }^{93}$

Burada kullanılan yemek figürünün bir mecaz olması kuvvetle muhtemeldir. Bilindiği üzere ilim meclisleri Tarikat erbabınca "sofra" olarak anılır. Bir pirin bir yere sofrasını açması demek, irfan sofrasını açmak ve kendisine gelenleri irşat etmesi anlamında kullanilir. ${ }^{94}$

\subsubsection{Her Kapının Cünübü Farklıdır}

İmam Cafer Sadık Buyruğunun Alaca yazmasında cünüplük kapılara göre değişir. Şeriatta cünüplük, kişinin eşiyle cinsel ilişkide

\footnotetext{
89 Buyruk, 80.

90 Buyruk, 210.

91 Buyruk, 211.

92 Buyruk, 113.

93 Güzel, Hacı Bektaş Veli El Kitabı, 492.

94 Ahmet Taşğın, "İrfanın Anlam Kaybı ve Belirsizliği - Yesevîlikte Sofra Tutmak", 82-98
} 
bulunmasıyla olur. Tarikatta cünüplük, kişinin pirsiz olmasıdır. İkrarına ve ahdine vefa etmemesi, yalancı çıkmasıdır. Marifette cünüplük, nefsini bilmemektir. Hakikatte cünüplük ise kişinin kendi ayıbını örtüp elin ayıbını açmasıdır. Kırk makamın da cünüplüğü vardır. Bu da kissinin Dört Kapı hizmetini terk ederek rızasız şekilde ve başına buyruk iş yapmasıdır. ${ }^{95}$ Her cünüplüğün bir temizlenmesi vardır. Şeriat cünübü, su ile temizlenir. Tarikat cünübü, pir eliyle temizlenir. Marifet cünübü, mürşit eliyle temizlenir. Hakikat cünübü ise mürebbi eliyle temizlenir. ${ }^{96}$

\subsubsection{Her Kapının Abdesti Farklıdır}

İmam Cafer Sadık Buyruğunun Malatya yazmasında, her kap1nın abdesti farklı şekillerde anlatılmıştır. Buna göre, Şeriat abdesti suyla, Tarikat abdesti pire biat etmekle, Marifet abdesti nefsini bilip Rabbini tanımakla, Hakikat abdesti ise kendi ayıplarını görüp diğerlerinin ayıplarını örtmekle olur. ${ }^{97}$

İmam Cafer Sadık Buyruğunun İzmir yazmasında da abdestin her kapıda farklı olduğu benzer ifadelerle anlatılır. Buna göre, Şeriat abdesti suyla, Tarikat abdesti pir elinden biat etmekle, Marifet abdesti nefsini bilip Rabbini tanımakla, Hakikat abdesti kendi ayıplarını görüp diğer kişilerin ayıbını örtmekle olur. ${ }^{98}$

\subsubsection{Her Kapının Günahları Farklıdır}

Alevilikte gönül temizliğine büyük önem verilir. İnsanın gönlü, Kâbe'ye eşdeğer tutulur ve gönül yıkanın Kâbe'yi yıkmak kadar büyük bir vebal altında kaldığı ifade edilir. Yazılı kaynaklarda bu hususa geniş şekilde yer verildiği gibi Alevi toplumunun belleğinde de bu değer yargısı önemli yer işgal eder. Sadece günah işlemek değil, günahı akla ve gönle getirmek bile kötü bir durum olarak görülür. İmam Cafer Buyruğunun Hacıbektaş-1 yazmasında, bir müminin kalbine küfür veya fesat geldiğinde meleklerin bunu günah defterine yazıp yazmadığ1 sorulur. Cevap, Dört Kap1 düsturunca verilir. Buna göre fetvaca yazılmaz ama takvaca yazılır. SSeriatta ve Tarikatta günah yazılmaz ama Hakikatte günah yazılır. Çünkü Hakikat kapısı evliyalık makamıdır. Evliyanın gönlü fesattan, küfürden uzak olmalıdır. Evliyanın aklına bir fesat gelince, kişinin evliyalığı düşer. O fesat, gittikten sonra kissi yine evliya olur. ${ }^{99}$

\footnotetext{
95 Buyruk, 185.

96 Buyruk, 185-186.

97 Buyruk, 211.

98 Buyruk, 141.

99 Buyruk, 230.
} 


\subsubsection{Her Kapının Şahitleri Farklıdır}

Dört Kapı'nın her kapısında şahitlerin de farklı olduğu dikkat çeker. İmam Cafer Buyruğunun İzmir yazmasında, Şeriat şahidinin iki kişi olduğu ifade edilir. Tarikat şahidi pirdir. Marifetin şahidi ikrar, Hakikatin şahidi ise imandır. 100

\subsection{Dört Kapı İçin Kullanılan Mecazlar}

Aleviliğin yazılı kaynaklarında Dört Kapı değişik mecazlarla ifade edilmiştir. Mecazlarda dikkat çeken hususların başında, birbirini tamamlayan unsurların kullanılması gelir. Mesela rüzgâr, ateş, su ve toprak mecazında dört unsur [anasır] birlikte verilir. Ağaç, dal, yaprak ve yemiş mecazında da benzer şekilde birbirini tamamlayan unsurlar söz konusudur. Ayrıca buradaki mecazda aşamalar da dikkati çeker. Ağaç olmadan dal, dal olmadan yaprak, yaprak açmadan yemiş olmaz. Benzer bir mecaz, ten, et, kemik ve can unsurlarıyla yapılır. Gemi, deniz, dalgıç ve inci mecazları da bunlar gibidir.

Aşağıdaki tabloda Dört Kapı için yapılan mecazlar özce verilmiştir.

Tablo: Dört Kapı hakkında yapılan mecazlar

\begin{tabular}{|c|c|c|c|}
\hline $\begin{array}{l}\text { Şeriat Ka- } \\
\text { pisi }\end{array}$ & $\begin{array}{l}\text { Tarikat } \\
\text { Kap1s1 }\end{array}$ & $\begin{array}{l}\text { Marifet } \\
\text { Kap1s1 }\end{array}$ & $\begin{array}{l}\text { Hakikat } \\
\text { Kap1s1 }\end{array}$ \\
\hline Rüzgâr & Ateş & $\mathrm{Su}$ & Toprak $^{101}$ \\
\hline [Rüzgâr] & Ateş & $\mathrm{Su}$ & Toprak $^{102}$ \\
\hline Göz & Kulak & Ağ1Z & Burun 103 \\
\hline Gemi & Deniz & Dalgıı & İnci 104 \\
\hline İlim & İman & Din & Amel $^{105}$ \\
\hline Ten & Et & [Kemik] & Can $^{106}$ \\
\hline Kap1 & Essik & Söve [Ka- & Kilit107 \\
\hline
\end{tabular}

100 Buyruk, 123.

101 Oytan, Bektaşiliğin İçyüzü, 1/83; Özmen, Alevi-Bektaşi Şiirleri Antolojisi, 548; Şeyh Safi Buyruğu, 451.

102 Durbilmez, Muhyiddin Abdal Divant, 124-127.

103 Oytan, Bektaşiliğin İçüzü, 1 / 83.

104 Buyruk, 18.

105 Buyruk, 18-19.

106 Buyruk, 19. 


\begin{tabular}{|c|c|c|c|}
\hline & & sa] & \\
\hline Çerağ & Fitil & Yağ & $\begin{array}{r}\text { Şule } \\
\text { [Issik } 108\end{array}$ \\
\hline Ağaç & Dal & Yaprak & Yemiş 109 \\
\hline Gemi & Rüzgâr & Okyanus & Okyanus ${ }^{110}$ \\
\hline Cebrail & Mikail & İsrafil & Azrail $^{111}$ \\
\hline Şartım & Terkim & Derdim & Merdim $^{112}$ \\
\hline $\begin{array}{l}\quad \text { Ceberrut } \\
\text { [büyüklük] } \\
\text { âlemi }\end{array}$ & \begin{tabular}{l}
\multicolumn{2}{c}{ Melekût } \\
[ruhlar ve \\
melekler] \\
âlemi
\end{tabular} & $\begin{array}{l}\text { Lahut } \\
\text { [yücelik] âle- } \\
\text { mi }\end{array}$ & \begin{tabular}{ll}
\multicolumn{1}{r}{ Nasut } & [in- \\
sanlık] & âle- \\
mi $^{113}$ &
\end{tabular} \\
\hline $\begin{array}{l}\text { Âlem-i na- } \\
\text { sut }\end{array}$ & $\begin{array}{l}\text { Âlem-i } \\
\text { ceberut }\end{array}$ & $\begin{array}{l}\text { Âlem-i me- } \\
\text { lekût }\end{array}$ & $\begin{array}{l}\begin{array}{c}\text { Âlem-i la- } \\
\text { hut114 }\end{array} \\
\text {. }\end{array}$ \\
\hline İşitmek & Görmek & Anlamak & Bilmek $^{115}$ \\
\hline $\begin{array}{l}\text { Anadan } \\
\text { doğmak }\end{array}$ & $\begin{array}{l}\text { İkrar } \\
\text { vermek }\end{array}$ & $\begin{array}{l}\text { Nefsini } \\
\text { bilmek }\end{array}$ & $\begin{array}{l}\text { Hakk'1 } \\
\text { özünde } \\
\text { mak }^{116}\end{array}$ \\
\hline $\begin{array}{l}\text { Yakin ol- } \\
\text { mak }\end{array}$ & \begin{tabular}{l}
\multicolumn{2}{c}{ Kendi ha- } \\
lini ispat \\
etmek
\end{tabular} & $\begin{array}{l}\text { Sözün an- } \\
\text { lamını bilmek }\end{array}$ & $\begin{array}{l}\text { Vasil } \\
\text { mak }^{117}\end{array}$ \\
\hline $\begin{array}{l}\text { Kulluk et- } \\
\text { mek }\end{array}$ & Bilmek & Ermek & Görmek ${ }^{118}$ \\
\hline Bilmek & Amel kil- & - & Hakk'a er- \\
\hline
\end{tabular}

107 Buyruk, 19.

108 Buyruk, 19.

109 Bisati, Şeyh Safi Buyruğu, 37.

110 Bisati, Şeyh Safi Buyruğu, 37.

111 Buyruk, 243; Güzel, Hacı Bektaş Veli El Kitabı,452; Koçak, "Erkânnâme: 2", 71-144.

112 Şeyh Safi Buyruğu, 91.

113 Güzel, Hacı Bektaş Veli El Kitabı, 452; Buyruk, 243; Koçak, "Erkânnâme: 2", 71-144.

114 Oytan, Bektaşiliğin İçyüzü, 1 / 83.

115 Buyruk, 19.

116 Oytan, Bektaşiliğin İçyüzü, 1/83; Özmen, Alevi-Bektaşi Şiïleri Antolojisi, 548.

117 Buyruk, 18.

118 Buyruk, 18. 


\begin{tabular}{|c|l|l|l|}
\hline & mak & & mek $^{119}$ \\
\hline $\begin{array}{c}\text { Haramlar1 } \\
\text { terk etmek }\end{array}$ & $\begin{array}{c}\text { Benliği } \\
\text { terk etmek }\end{array}$ & $\begin{array}{c}\text { Terki terk } \\
\text { etmek }\end{array}$ & $\begin{array}{c}\text { Şüpheli } \\
\text { seyleri } \\
\text { etmek }\end{array}$ terk \\
\hline Hâl & $\begin{array}{c}\text { Geçip } \\
\text { gelmek }\end{array}$ & $\begin{array}{c}\text { Talip ol- } \\
\text { mak }\end{array}$ & $\begin{array}{c}\text { Hakk'1 bil- } \\
\text { mek }^{121}\end{array}$ \\
\hline
\end{tabular}

\subsection{Dört Kapının Ana Hatları}

Dört Kap1, bir eğitim ve gelişim programıdır. Doğal olarak her kapının içeriği farklıdır. Her kapı, kendisinden bir önceki kapıdan daha derin ve içkin bir kapsama sahiptir. Hak âșıklarından Hatayi (16. yüzy1l) kelamınca söyleyecek olursak, "Şeriatın ince yollar vardır / Marifetin gonca gülleri vardır / Hakikatin derin gölleri vardır."122

Şeriat, Tarikat, Marifet ve Hakikat kapılarının genel kapsamlar1n1, kaynaklara bakarak şöyle özetlemek mümkündür.

\subsection{1. Şeriat Kapısının Ana Hatları}

Dört Kapı'nın birincisi, başlangıç aşamasını temsil eden Şeriat kapısıdır. Şeriat kapısı özce Müslüman olmayı ve Allah'ın emir ve yasaklarına uymayı ifade eder. Bu kapıdaki kişilere "abid" denir. ${ }^{123}$

İmam Cafer Buyruğunun İzmir yazmasına göre, ulu bir kapı olan Şeriat, hakkı batıldan seçer. ${ }^{124}$ Şeriat, Hz. Muhammed'e itaat etmektir. Bu nedenle kişi, ancak Şeriata değer verirse takvaya ulaşabilir. ${ }^{125}$ Muhyiddin Abdal'a (16. yüzy1l) göre, "Şeriatın şartı Kur'an'dır."126 İmam Cafer Buyruğunun İzmir yazmasında Şeriat, Hz. Muhammed'in sözleri olarak gösterilir. ${ }^{127}$ Şeriat kapısında kişi, önce Müslüman olmalıdır. Çünkü Müslüman olmayan mümin olamaz. ${ }^{128}$ Kaygusuz Abdal (ölm. 1444) da, "Şeriatı Muhammed'e verdiler / Tarikat üstüne bir yol kurdular / Marifet babında sual sordular

\footnotetext{
119 Buyruk, 26.

120 Erkânnâme-1, 133.

121 Durbilmez, Muhyiddin Abdal Divant, 124-127.

122 Özmen, Alevi-Bektaşi Şiirleri Antolojisi, 2/157.

${ }^{123}$ Hacı Bektaş Veli, Makâlât, 67.

124 Buyruk, 74.

125 Buyruk, 72.

126 Durbilmez, Muhyiddin Abdal Divanı, 124-127.

127 Buyruk, 93.

128 Buyruk, 93.
} 
/ Hakikat var Hakikatten içeri"129 misralarında Şeriatın Hz. Muhammed'in şanına geldiğini bildirir.

Şeyh Safi Buyruklarından birinde Şeriat kapısı, Allah'in emir ve yasaklarına uymak, O'nun davet ettiği yolda gitmek, Allah'a itaat etmek ve Hz. Muhammed'in sünnetini kabul etmek olarak tarif edilir. Nitekim ayette, "Allah'a itaat edin ve elçiye ve sizden olan buyruk sahiplerine itaat edin (Nisa, 4 / 59) diye emredilir. ${ }^{130}$ Yunus Emre de Şeriatı Allah'in emir ve yasakları kapsamında açıklar: "illk kapı Şeriattır / Emri nehyi bildirir / Yuya günahlarını / Her bir Kur'an hecesi."131

Şeyh Safi Buyruklarından bir yazma metne göre, Şeriat, ilim öğrenmek ve dinin buyruklarını yerine etmektir. Derviş olan kişi, sürekli kendini geliştirmeli, mertebe kaybetse bile yükselmeye gayret etmelidir. Gelişme, bir menzil ve bir mertebe ileri gitmektir. Talip, gerçek ilme göre amel etmelidir. Çünkü ilimsiz amelin faydası yoktur. $\mathrm{Bu}$ nedenle derviş, Şeriat ilmini iyice öğrenip bu ilmi kendine elbise etmelidir. Bütün sırları bu bilgi ile sır edip halktan gizlemelidir. Sırrı sır eylemek, Hakk'ı yüceltmektir. Sırrı açıklamak ise büyük günahlar arasındadır. ${ }^{132}$

İmam Cafer Buyruğunun İzmir yazmasına göre Şeriat, beş nesne ile bağlanır, beş nesne ile açılır. 1) Ahmaklık ile bağlanır, itaat ve namaz ile açılır. 2) Nefs ile bağlanır, ibadet ile açılır. 3) Asilik ve acele ile bağlanır, niyaz etmekle açılır. 4) Küfür ile bağlanır, iman ile açılır. 5) Şirk ile bağlanır, hayır ve ihsan ile açılır. ${ }^{133}$

1612 tarihli Manisa Şeyh Safi Buyruğunda Şeriat, ateşe benzetilir. Çünkü tüm çiğler ateşle pişer. Bu nedenle Tarikatı, Şeriat içinde ortaya çıkarmak gerekir. ${ }^{134}$ Yani Şeriat olmadan Tarikat olmaz. Tarikat, Şeriatın bünyesinden çıkar ve filiz verir. Yine aynı esere göre, kişinin Şeriatı sürekli olmalıdır. Kişi Şeraitte kararlı olmadan derviş olamaz. Eğer ilmini artırır âlim olursa, nur üstünde nur olur.135 İmam Cafer Buyruğunun İzmir yazmasında da, Tarikatın ön şartı Şeriat olarak gösterilir: "Bir kimsede Şeriat şart olmasa Tarikata giremez." 136

\footnotetext{
129 Oytan, Bektaşiliğin İçüzü, 1/ 147.

130 Bisati, Şeyh Safi Buyruğu, 20.

131 Özmen, Alevi-Bektaşi Şiirleri Antolojisi, 1/88.

132 Erkânnâme-1, 133.

133 Buyruk, 74.

134 Bisati, Şeyh Safi Buyruğu, 20.

135 Bisati, Şeyh Safi Buyruğu, 29.

136 Buyruk, 77.
} 


\subsubsection{Tarikat Kapısının Ana Hatları}

Gelişmeye ve ilerlemeye azmetmiş kişi, Şeriat kapısının gereklerini yerine getirdikten sonra Tarikat kapısına ulaşır. Kişinin Tarikat kapısına ulaşması için Şeriat kapısını tamamlaması ve gereklerini sürekli yerine getirmesi gerekir. Tarikat kapısına ulaşan kişi mümin olmaya adım atmıştır. Kalp gözü açılmaya, kalbi iman ile dolmaya başlamıştır. Bu kapıdaki kişilere "zahid" denir. 137

Şeyh Safi Buyruklarından bir yazmaya göre, Şeriatını tamam eyleyen kişi, Tarikata girer. Tarikatta da imanı saf ve iradesi kuvvetli olmalıdır. Bir rehberin emrine girip Tarikat erkânlarını yerine getirmelidir. ${ }^{138}$ Tarikatta iman kapısı kişiye açılır. Kırıkkaleli Hasan Dede'nin (ölm. 1603) ifadesiyle, "Mümin olanlara Tarikat gerek"tir. 139

İmam Cafer Buyruğunun İzmir yazmasında, Tarikat sözleri Hz. Ali'ye atfedilir. Tarikata ayağını basan kişi “insaniyetliği"ni belli etmelidir. Çünkü bir kutsi hadiste Hakk Teâla, Hz. Muhammed'e hitaben, "Ya Muhammed bu cihant yarattım, insan için. Ve insant yarattım kendim için" buyurur. ${ }^{140}$

1612 tarihli Manisa Şeyh Safi Buyruğuna göre ise, "Tarikat bir doğru yoldur”. Kişi, doğru yoldan Allah'a gider. Çünkü Tarikat, erenler dergâhında "Bizi doğru yoluna ilet" (Fatiha 1 / 6) ayetinden ibarettir. Tarikatta yerine getirilmesi gereken issler, vaciptir ve sünnettir. Bunlar1 yerine getirmek gerekir. ${ }^{141}$ Yunus Emre'nin, "İkincisi Tarikat / Kulluğa bel bağlaya / Yola doğru varanı / Yarlıgaya [bağışlamak] hocası"142 misraları da Tarikatı yol ve iman kavramları temelinde açıklar.

İmam Cafer Buyruğunun İzmir yazmasında Hz. Muhammed'in, Tarikatın yedi nesneyle açıldığını ve yeni nesneyle kapandığını söylediği bildirilir: 1) Pahıllık [cimrilik, bencillik] ile bağlanır, kerem ile aç1lır. 2) Cahillik ile bağlanır, inayet ile açılır. 3) Habislik [kötülük, alçaklık] ile bağlanır, hidayet ile açılır. 4) Dünyalık ile bağlanır, kanaat ile açılır. 5) Şeytanlık ile bağlanır, rahmanlık [merhamet] ile açılır. 6) Kibri haset ile bağlanır, akil-nakil [bilgisi] ile ve batın gözü ile açılır. 7) Hayret [şaşkınlık] ile bağlanır, kerem ile açılır. ${ }^{143}$

\footnotetext{
137 Hac1 Bektaş Veli, Makâlât, 67.

138 Erkânnâme-1, 167-170.

139 Özmen, Alevi-Bektaşi Şiirleri Antolojisi, 3/27.

140 Buyruk, 94.

141 Bisati, Şeyh Safi Buyruğu, 23.

142 Özmen, Alevi-Bektaşi Şiirleri Antolojisi, 1/88.

143 Buyruk, 74-75.
} 
Kişi tarikat kapısında gönlünde imanı inşa eder, onu arttırır. Gönül gözünü açmanın çabası içinde olur. Tarikat kapısını tamam eden kişi, Marifet kapısına ulașır ve gelişimine devam eder.

\subsubsection{Marifet Kapısının Ana Hatları}

Marifet, Tarikat Kapısı tamamlandıktan sonra ulaşılan kapıdır. Dört Kapı'nın üçüncüsüdür. Marifet kapısından öngörülen hedef Allah'1 gönül gözü ile görmektir. Bu kapıdaki kişilere "arif" denir. ${ }^{144}$ Hatayî de arif olmak için Marifet tohumlarına sahip olmak gerektiğini söyler: "Beş vakit farzdır sünneti de kaç / Özünü tanış da müşkülünü seç / Hakikat tarlasina marifetler saç / Ek nazar eyle de hemen arif ol". ${ }^{145}$

Seriatla birlikte Tarikat kapısının da gerekleri yerine getirilmelidir. Şeyh Safi Buyruğu yazmalarından birine göre, Tarikat edeperkânın tam olarak yerine getirmeyen kişi, Tarikattan Marifete ulaşamaz. Böyle kişi susuz ve çorak yere benzer. Çünkü susuz ve çorak yerde ne ot, ne de ağaç biter. Meyve de olmaz, lezzet de olmaz. Böyle yerlerde hiçbir canlı huzur bulamaz, memleket harap olur. ${ }^{146}$

1612 tarihli Manisa Şeyh Safi Buyruğuna göre, Marifet kapısındaki müminler birbirinin aynasıdır. Bunlar artık güzel ahlakın son kertesine ulaşmış kişilerdir. Bu kişilerin hulkı [yaratılış, tabiat, huy, ahlak] Hz. Muhammed'e, mürüvveti [yiğitlik, cömertlik, insaniyet] Hz. Ali'ye benzemelidir. Bu şartları tassıyanlar Muhammed Ali dostu olurlar, taşımayanlar olamazlar. ${ }^{147}$

Şeyh Safi Buyruklarından bir yazmada, Marifetin mana olduğu belirtilir. Manadan kastedilen ise maksuttur. Maksuttan kastedilen de Yüce Allah'nn cemalini gönül gözü ile görmektir. Yetmiş iki milletin tamamı yani bütün insanlık, Allah'ın cemalini görmek ister. Hakk Teâlâ ise sadece bunu mümin kullarına bahşeder. Hz. Peygamber'in buyurduğu üzere, "Müminin kalbi Allah'ın evidir; müminin kalbi Allah'ın arşıdır". ${ }^{148}$ Yunus Emre de can gözünün Marifet kap1sında açıldığını söyler: "Üçüncüsü Marifet / Canın gözünü açar / Bu mana sarayının / Arşa değer yücesi." 149

Hacı Bektaş Veliye nispet edilen Makâlât adlı kitapta, her şey can ile dirildiği, canın ise Marifetle dirildiği söylenir. Marifetli can,

\footnotetext{
144 Hacı Bektaş Veli, Makâlât, 67.

145 Özmen, Alevi-Bektaşi Şiirleri Antolojisi, 2/153.

146 Erkânnâme-1, 167-170.

147 Bisati, Şeyh Safi Buyruğu, 36.

148 Erkânnâme-1, 171-173.

149 Özmen, Alevi-Bektaşi Şiirleri Antolojisi, 1/88.
} 
erenlerin canıdır. Marifetsiz canlar ise hayvanların canıdır. "Âşık olanların tenleri ölür ama canları ölmez". ${ }^{150}$

İmam Cafer Buyruğunun İzmir yazmasına göre, Marifet makaminda olanlara cennetin sekiz kapısı açılır ve yüzlerine yedi tamunun [cehennem] kapısı bağlanır. ${ }^{151}$

\subsubsection{Hakikat Kapısının Ana Hatları}

Kemal basamaklarının sonuncusu, Hakikat kapısıdır. Hakikat kapısında öngörülen hedef, kissinin Allah'a ulaşması, kendi özünde Allah'ı bulmasıdır. Bu kapıdaki kişilere "muhip" denir. ${ }^{152}$

İmam Cafer Buyruğunun İzmir yazmasına göre Hakikat, Marifetten ortaya çıkar. ${ }^{153}$ Çünkü kemal basamaklarında Marifetten sonra Hakikat gelir. Marifetin şartlarını yerine getirmeyen kişi, Hakikat kapısına eremez. Aynı metne göre Hakikat kapısı, evliya makamıdır. Evliyanın kalbi her türlü kötülükten beridir. Ancak kalbine bir fesat gelirse o kişi, evliyalıktan düsser. ${ }^{154}$ Yunus Emre Hakikat kapısından, evliyalığın bir diğer adı olan velayet şeklinde bahseder: "Dört Kapı'dır Kırk Makam yüz altmış menzili var / On'[a] erene açılır velayet derecesi." 155

İmam Cafer Buyruğunun İzmir yazmasına göre, Hakikat Hakk Teâlâ'nındır ve Hakk Teâlâ üzeredir. Hakikat menziline ulaşan kişi Hakk'a ulassmış sayılır. ${ }^{156}$ Şeyh Safi Buyruğunun bir yazmasında Hakikatin hak olduğu, burada kişinin hatası ve şüphesi olmadığ1 ve tek amacın Allah olduğu söylenir. Bu makamda perde yoktur ve bir olan gönüllerin muradı sadece Allah'tır. ${ }^{157}$ Yunus Emre bir şiirinde Hakikat kapisına ulaşan kişinin "her şey"i bulduğunu söyler: "Dördüncüsü Hakikat / Eren her şeyi bula / Bayram ola gündüzü / Kadir ola gecesi." 158

Şeyh Safi Buyruklarından bir yazmada bildirildiğine göre, Hakikat kapısına ulaşmak ana hedeftir. Çünkü Hakikat toprak gibidir. Nasıl ki, toprağa ne atarsan bir şeyler elde edersin, Hakikat kap1sında da kişi, ne amel ederse bir karşılığını görür. Hakikate varma-

\footnotetext{
150 Hacı Bektaş Veli, Makâlât, 86.

151 Buyruk, 75.

152 Hacı Bektaş Veli, Makâlât, 67.

153 Buyruk, 75.

154 Buyruk, 193.

155 Özmen, Alevi-Bektaşi Şiirleri Antolojisi, 1/181.

156 Buyruk, 75.

157 Erkânnâme-1, 173-182.

158 Özmen, Alevi-Bektaşi Şiirleri Antolojisi, 1/88.
} 
yan kişinin amelleri, toprağa saçılmadığı için ürün vermeyen tohuma benzer. Gönüldeki Hakikat toprağı, Marifet suyuyla sulanınca bol ürün verir, hasadı bereketli olur. Böyle ekini hakkıyla biçmek, dövmek ve savurmak gerekir. Savururken de dikkat etmeli, daneyi rüzgâra kaptırmamalıdır. ${ }^{159}$ Âş1k Nesli (18. yüzyıl) de "Marifet tohumu" mecazını dile getirir: "Nesli bu dünyaya ayaktan geçip / Hakikatle konup Hak ile göçüp / Marifet tohumun tarlaya saçıp / Ektiğin hasılı biçebildin mi?"160

Hakikat kapısında dikkat çeken bir diğer özellik bu kapının birlik makamı olmasıdır. Şeyh Safi Buyruklarından birine göre, "Hakikat Hak evidir. Onda Hak olur batıl olmaz. Hem iman evidir onda küfür olmaz. Ayrıca birlik makamıdır, hiç ikilik olmaz. Çünkü Hakk birdir iki olmaz”. ${ }^{161}$ Nitekim Hatayî (16. yüzy1l) de Dört Kapı'dan geçenlerin bütün kavramlardan kurtulduğunu söyler, çünkü Hakikat kapısında her şey birdir: "Geçmek gerek Dört Kapi'dan / Kurtulasin mürebbiden / Mürebbiden musahipten / Eli gerek yol ehlinin”. ${ }^{162}$ Kul Hüseyin ise birlik makamında yani Hakikat kapısında insan-1 kâmil olunduğunu söyler: “Cemi'-ül-cem'de cem' olmuş özü / Hakikat kâmil-i insana erdim”. ${ }^{163}$ Teslim Abdal (17. yüzy1l) da Dört Kapı'y1 tamam edenlerin Hakikat kapisında birliğe ulasstığına vurgu yapar: "Teslim Abdal daim yüksek uçar mı? / Erenlere teslim olan kaçar mı? / Dört Kapıdan Kırk Makamdan geçer mi? / Bir olup birliğe yeten ağlar mi?"164

Şeyh Safi Buyruğu olduğu anlaşlan bir metne göre, toprak, herkesin çirkin bulup sakındığı nesneleri bile kabul eder. Onun pisliğini yok ederek ona da toprak denmesini sağlar. Ama toprağa uyum sağlamaz ve tekrar çirkinliğini gösterirse yine çirkin ismiyle anılır. Yani çirkin nesneler toprağa ve onun temizliğine zarar veremez. Hakikat kapısına eren kişiler de hem kendini hem de kendine gelen kişiyi toprak gibi kötü huylardan temizler. İște Hakikat ehli de toprağa benzer. Küfrü imana, çirkini güzele çevirir. Şüpheli şeylerden hem kendisi uzak durur hem de kendine geleni uzak tutar. ${ }^{165}$ Alevi erenlerinin sıklıkla ifade ettiği "küfür içindeki iman" da budur. Hakikat ehlinin küfür içindeki gönüllerdeki imanı bulup onu ihya et-

\footnotetext{
159 Erkânnâme-1, 173-182.

160 Özmen, Alevi-Bektaşi Şiirleri Antolojisi, 3/15.

161 Erkânnâme-1, 173-182.

162 Özmen, Alevi-Bektaşi Şiirleri Antolojisi, 2/139.

163 Özmen, Alevi-Bektaşi Şiirleri Antolojisi, 2/348.

164 Özmen, Alevi-Bektaşi Şiirleri Antolojisi, 3/96.

165 Erkânnâme-1, 173-182.
} 
mesidir. Gönülleri küfürden temizlemesi ve iman hakikatleriyle doldurmasidir.

Tablo: Dört Kapı'da öngörülen hedefler.

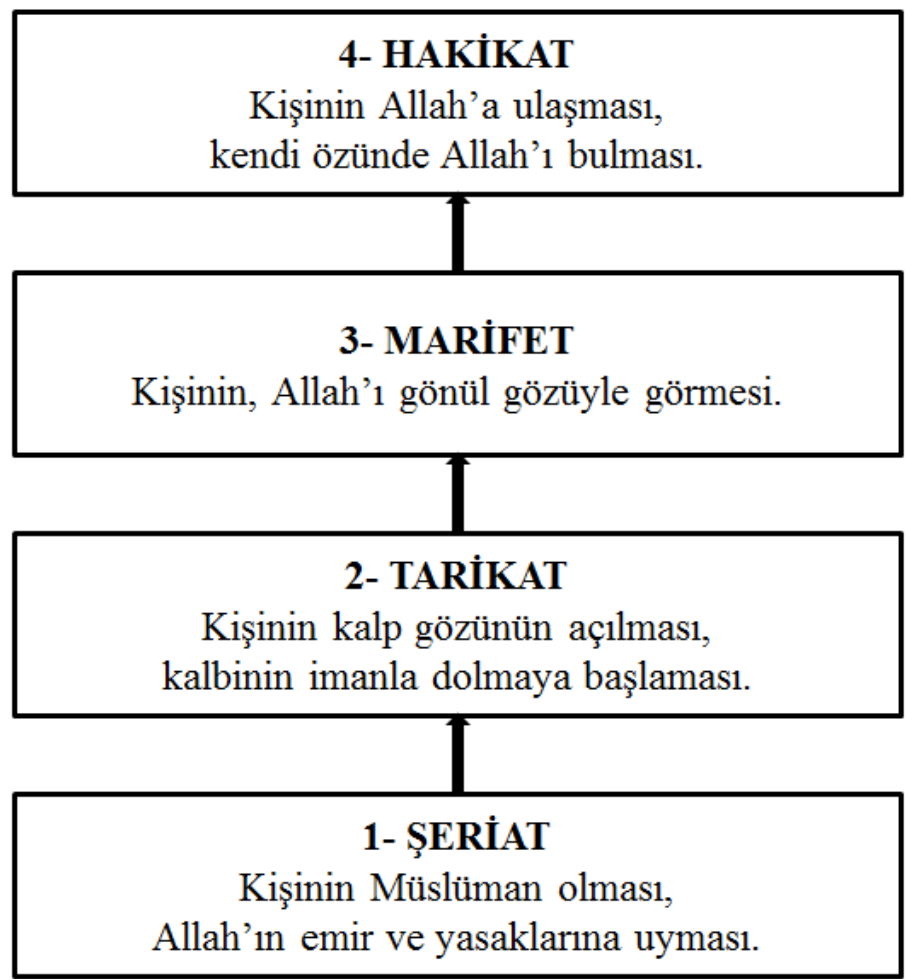

\section{Sonuç ve Değerlendirme}

Aleviliğin iç metinlerinde Dört Kapı kavramı Allah’tan Cebrail vasitasiyla Hz. Muhammed'e, Hz. Muhammed'den Hz. Ali'ye, Hz. Ali'den evlatları Hz. Hasan ile Hz. Hüseyin'e, On İki İmam'dan Hoca Ahmet Yesevî'ye ve Safevi Tarikatının kurucusu Şeyh Safi'ye, Hoca Ahmet Yesevî'den de Hacı Bektaş Veli'ye intikal etmisstir. Aleviliğin yazılı kaynakları, Dört Kapı kavramının kaynağını tümüyle İslâmi kaynaklara dayandırır. Bunlar başta Kur'an-1 Kerim'in ayetleri olmak üzere Hz. Muhammed, Hz. Ali ve İmam Cafer Sadık gibi İslâmi kişiliklerin buyrukları ve uygulamalarıdır.

Aleviliğin yazılı kaynaklarını dikkatle incelediğimizde Dört Kapı, kimi temel özellikleri ile ön plana çıkar. Bu temel özellikler, bir eğitim programı olması, bir süreç olması, hiç birinin eksik olmaması, disiplinin şart olması, her kapı için ayrı bir strateji uygulanması, 
Şeriatın zahir, diğerlerinin batın olduğu, Dört Kapı'yı tamamlayanın evliya olduğu şeklinde sıralanabilir.

Dört Kapı'nın en önemli özelliği bir eğitim programı olmasıdır. Alevilikteki eğitim sistemi, bir eğitim sisteminde olması gereken bütün bileşenlere sahiptir. Alevilikteki eğitim sisteminin programı da Dört Kapı'dır. Bir eğitim programı olarak tasarlanan Dört Kap1 hem bireysel ve hem de toplumsal eğitimin temelini oluşturur. Dört Kap1, bir eğitim ve gelişim programıdır. Doğal olarak her kapının içeriği farklıdır. Her kapı, kendisinden bir önceki kapıdan daha derin ve içkin bir kapsama sahiptir.

Kaynaklarda Dört Kapı programı içinde ilerleyen kişiler için farklı özellikler ifade edilmiştir. Çünkü Dört Kapı sürekli ilerlemeyi ve tekâmül etmeyi öngörür. Bu farklı özellikleri, selam, baba, kardeş, yemek usulü, cünüplük, abdest, günah ve şahitler şeklinde sıralamak mümkündür.

Aleviliğin yazılı kaynaklarında Dört Kapı değişik mecazlarla ifade edilmiştir. Mecazlarda dikkat çeken hususların başında birbirini tamamlayan unsurların kullanılması gelir.

Kaynaklardan Dört Kap1 programında genel bir uyum olduğu, kaynaklardaki bilgilerin birbirini tamamladığı görülmektedir. En temel farklılık yedili ve onlu sistemler şeklinde tasarlanmış olmas1dır. Bu tasarımlarda da makamların birçoğu ve programın ana yapısı ve hedefleri aynıdır. Dört Kapı'nın birincisi, başlangıç aşamasını temsil eden Şeriat kapısıdır. Şeriat kapısı özce Müslüman olmayı ve Allah'in emir ve yasaklarına uymayı ifade eder. Kendini gelissmeye ve ilerlemeye adamış kişi, Şeriat kapısının gereklerini yerine getirdikten sonra Tarikat kapısına ulaşır. Kişinin Tarikat kapısına ulaşması için Şeriat kapısını tamamlaması ve gereklerini sürekli şekilde yerine getirmesi gerekir. Tarikat kapısına ulaşan kişi mümin olmaya adım atmıştır. Kalp gözü açılmaya, kalbi iman ile dolmaya başlamıştır. Marifet, Tarikat Kapısı tamamlandıktan sonra ulaşılan kap1dır. Dört Kapı'nın üçüncüsüdür. Marifet kapısından öngörülen hedef Allah'ı gönül gözü ile görmektir. Kemal basamaklarının sonuncusu, son kapı Hakikattir. Hakikat kapısında öngörülen hedef, kişinin Allah'a ulaşması, kendi özünde Allah'ı bulmasıdır. Hakikat kapisı evliya makamidir.

Alevi olmayan diğer Müslüman toplumlarda Dört Kap1 kavramı ve Dört Kapı'nın makamları bu çalışmanın dışında bırakılmıştır. Bu konular ayrı başlıklar altında çalışılmalıdır. 


\section{KAYNAKÇA}

Bisati. Şeyh Safi Buyruğu. Nşr. Ahmet Taşğın. Konya: Çizgi Yayınlar1, 2003.

Buyruk. Nşr. Sefer Aytekin. Ankara: Emek Yayımevi, 1958.

Demir Baba Velâyetnâmesi İnceleme-Tenkitli Metin. Nşr. Filiz Kılıç - Tuncay Bülbül. Ankara: Grafiker Yayınc1lık, 2011.

Durbilmez, Bayram. Muhyiddin Abdal Divanı Ínceleme-Tenkitli Metin. Doktora Tezi, Firat Üniversitesi, 1998.

Eraslan, Kemal. Yesevî̀nin Fakr-nâmesi. Ankara: Hoca Ahmet Yesevî Uluslararası Türk-Kazak Üniversitesi Yayınları, 2016.

Erdem, Cem-Topuzkanamıs, Ersoy. "Hac1 Kırzade Hüseyin Hüsnü Baba Erkânnâmesi”, Alevilik-Bektaşilik Araştırmaları Dergisi, 10 (2014): 115-139.

Erden, Münire. Eğitim Bilimlerine Giriş. Ankara: Arkadaş Yayınlar1, 2011.

Erkânnâme-1. Nşr. Doğan Kaplan. Ankara: Türkiye Diyanet Vakfı Yayınları, 2007.

Gümüşoğlu, Dursun - Yıldırım, Rıza. Bir Bektaşi Erkânnamesi: 1313 Tarihli Bir Erkânname Metni. İstanbul: Horasan Yayınları, 2006.

Güzel, Abdurrahman. Hacı Bektaş Veli El Kitabı. Ankara: Akçağ Yayınları, 2011.

Hünkâr Hacı Bektaş Veli. Makâlât. Nşr. Ali Yılmaz-Mehmet Akkuş-Ali Öztürk, Ankara: Türkiye Diyanet Vakfı Yayınları, 2015.

Koçak, Yunus. "Arnavutluk Devlet Arşivlerinde Bulunan Türkçe Yazma Eserler/Erkânname: 2", Türk Kültürü ve Hacı Bektaş Veli Araştırma Dergisi, 33 (2005): 71-144.

Koçak, Yunus. "Şah İbrahim Ocağı'ndan Gelen Bir Şeyh Safi Buyruğu”. Hac1 Bektaş Veli Araştırma Dergisi, 30 (2004): 63-118.

Otman Baba Velâyetnâmesi (Tenkitli Metin). Nşr. Filiz Kılıç - Mustafa Arslan - Tuncay Bülbül. Ankara: Grafiker Yayıncılık, 2007.

Oytan, M. Tevfik. Bektaşiliğin İ̧̧üzü: Dibi, Köşesi, Yüzü ve Astarı Nedir?. İstanbul: İstanbul Maarif Kitaphanesi ve Matbaas1, 1956.

Özmen, İsmail. Alevi-Bektaşi Şiirleri Antolojisi 1-4 Ciltler. Ankara: Kültür Bakanlığı Yayınları, 1998. 
Şeyh Safi Buyruğu. Nşr. Doğan Kaplan. Ankara: Türkiye Diyanet Vakfı Yayınları, 2015.

Taşğın, Ahmet. "İfanın Anlam Kaybı ve Belirsizliği - Yesevîlikte Sofra Tutmak", Geçmişten Geleceğe Hoca Ahmed Yesevî Uluslararası Sempozyumu Bildirileri- C. 1 (Ed. Ömer Kul vd.), İstanbul: ?, 2016.

Taşğın, Ahmet. Irak'ta Mezhep Çatışmaları Arasında Alevîler ve Bektaşîler, İstanbul: Önsöz Yayınc1lık, 2012.

Üçer, Cenksu. Alevî Nitelemeli Ocak / Gruplara Ait Tekke, Zâviye ve Dergâhlardaki Cami ve Mescidler, e-makâlât Mezhep Araştırmaları Dergisi, 11 (Güz 2018): 271-307

Yalçın, Alemdar-Yılmaz, Hacı. "Bir Ocağın Tarihi: Seyyid Hacı Ali Türabi Ocağı'na Ait Yeni Bilgiler”, Türk Kültürü ve Hacı Bektaş Veli Araştırma Dergisi, 26 (2003): 83-120

Yalçın, Yunus. Türk Edebiyatında Velâyetnâmeler ve Otman Baba Velâyetnâmesi. Yüksek Lisans Tezi, Erciyes Üniversitesi, 2007.

Katkı ve Teşekkür: Çalışmayı okuyarak değerli önerilerde bulunan Özlem Özdemir, Ali Tanrıverdi, Ali Timurtaş Özmen, Metin Küçük, Hüseyin Dedekargınoğlu, Cevat Gök ve Erkan Doğan'a teşekkür ederim.

\section{Summary}

Alevism has an education system and its curriculum is called The Four Gates. The Four Gates mean living humanly in harmony with self, society, nature and God; it aims to build society on the basis of consent. The Four Gates, which are called as Shariat, Tarikat, Marifet, and Hakikat (Sirr-1 Hakikat), represent the process to be followed in accepting, internalizing and transforming belief into a lifestyle.

In this study, the inner texts and written sources of Alevism were used. The concept of the Four Gates has been evaluated based on the works collected under the name of Buyruk, namely erkânnâme, velayetnâme, icazetnâme, and şecere, in addition to the pamphlets and poems of the Alevi scholars.

The source of the concept of the Four Gates is entirely based on Islamic references in the inner texts of Alevism. The fundamentals of the concept are based on the holy book of Muslims, Koran, and 
the words and attitudes of Prophet Muhammad, and two of the 12 imams, Ali and imam Cafer Sadik. There have been several sources indicating that the concept of Four Gates was reported to Prophet Mohammed during the Miraj.

In the inner texts of Alevism, the Four Gates stand out with some basic features. These basic features include such things as having a training program; maturing the person through the process; no gates can be missed; discipline is imperative; applying a separate strategy for each gate; the gate of Sharia is apparent; the others are hidden, and the people completing this process would be Saints.

The Four Gates is not mentioned as a direct training program in the inner texts of Alevism, but we can clearly see that it is a training program. It has a structure consisting of an education system, 1) student, 2) teacher, 3) program (curriculum), and 4) school. Students are called dervishes and suitors. People with titles such as baba, halifebaba, dedebaba, dede, pir, mürşit have teaching duties. Education institutions are replaced by ocak and dergâh. The curriculum consists of a broad education program called the Four Gates.

Among the prominent features of the concept of the Four Gates is a process, a path and a course. It is clearly understood from all sources that the Four Doors is a process from Sharia to Truth. This course, whose beginning and the end are clearly defined, starts by testimony to the existence of God and continues until the person reaches to God. The main goal of the Four Gates program, which takes the human from its raw state through successive stages, is eventually to reach God.

Another remarkable point about the concept of the Four Gates is that none of these doors can be missed during the education program. In other words, it is not possible for a person to reach Tarikat without fulfilling the Sharia, and to Hakikat without fulfilling the Marifet. Not only one of the Four Gates, but even if one of the authorities is missing, one cannot reach the intended goal. The Four Gates program has a content that is cumulative and does not revoke the old information. New knowledge and applications learned in one gate are put on top of the old and the accumulation of the past is not ignored, and not considered as unnecessary. If one of the gates or stages is missing, even if the person shows extraordinary abilities, it is advised to consider them as devil work.

It is imperative to be disciplined in order to achieve the goals envisaged in the concept of Four Gates. Particularly, the advice of the trainers and their consent are emphasized as the key factor for success. It is mandatory not only to ensure personal discipline, but 
also to control and construct the environments that may disrupt one's discipline. Such harmful environmental factors must be carefully eliminated.

Achieving the goals set for the Four Gates is possible by implementing different strategies at each Gate. In order to proceed through the Four Gates It is recommended as the basic strategy that the person should remain firm and mature in Sharia, be knowledgeable and beneficial in Tarikat, be honest, superior and stable in Marifet, and be permanent and loyal in the gate of Hakikat.

Another interesting point about the Four Gates is that Shariah is apparent and the others are secret or hidden. Basically, Prophet Muhammad is the owner and the communicator of the concept because the concept of Four Gates was taught directly to him. However since the religion and the Seriah were brought by him, Seriah is stressed strongly when talking about him. Ali, on the other hand, is not the owner of the Sharia because he is not a prophet. However, as the Sultan of the properties he is the custodian of the other three Gates.

The last feature that draws attention with the Four Gates program is that the person who completes this process will reach to a state of maturity and become an awliya. The person who has the knowledge of Sharia, Tarikat, Marifet and Hakikat and applies these principles in his life reaches to a state of sainthood. The ultimate purpose of is to take the person to final destination which is the state of awliya or sainthood. Those who reach this step find God in his essence and reunite with Him as the final destination.

Different features of the people advancing within the program of the Four Gates attract attention in the scholarly works. Accordingly, the salute, father, brother, eating style, ablution, sin and witnesses of each door are different.

The concept of Four Gates is expressed in dozens of different metaphors in the main texts of Alevism. The main feature that attracts attention in metaphors is the use of complementary elements. For example, the representation of Shariat as a tree, Tarikat as a branch, Marifet as a leaf, and Hakikat as a fruit can clearly demonstrate such existence of complementary elements. A branch cannot exist if there is no tree, a leaf cannot exist without a branch and a fruit cannot exist without a leaf. A similar metaphor has been used in the elements of skin, meat, bone and soul. There is a also a similar connection between ship, sea, diver and pearl metaphors.

The contents of the Four Gates differ from each other. The first of the Four Gates, Sharia, represents the initial phase. Shariah means 
being primarily Muslim and following Allah's commands and prohibitions. People at this door are called "abid". After the Sharia, the Tarikat door comes. The person who reaches the Tarikat door starts to become a believer and his heart began to fill with faith and the eyes of his heart open. The people at this gate are called "zahid". The gate of Marifet comes after this stage. The target envisaged in this gate is to see Allah through the eyes of heart. People at this gate are called "arif". The last stage towards maturity is the door called Hakikat. The goal envisaged at the Gate of Hakikat is that one reaches Allah and finds him in his essence. The people at this gate are called as "muhip". A few characteristics came to represent the gate of Hakikat. The first one is this gate is a state of union with Allah and the second is the person becomes earth at this gate as he dies. The earth as a metaphor is used because it accepts all objects even everyone avoids and finds ugly and cleans them. They come to the fore in the sources with a few features at the door of truth. The first is that it is a union authority, and the second is that the person is soil at this door. The metaphor of the earth finds its expression by accepting and clearing even the objects that everyone finds ugly and avoided. This is precisely the "Faith in profanity" that the Alevi saints often express. 